\title{
Article \\ Characterization of Yeasts Isolated from Parmigiano Reggiano Cheese Natural Whey Starter: From Spoilage Agents to Potential Cell Factories for Whey Valorization
}

\author{
Serena Martini ${ }^{1} \mathbb{D}$, Mattia Bonazzi ${ }^{1}$, Ilaria Malorgio ${ }^{1}$, Valentina Pizzamiglio ${ }^{2}$, Davide Tagliazucchi ${ }^{1} \mathbb{D}$ and \\ Lisa Solieri $1,2, *$ (D) \\ 1 Department of Life Sciences, University of Modena and Reggio Emilia, Via Amendola, 2-Pad. Besta, \\ 42122 Reggio Emilia, Italy; serena.martini@unimore.it (S.M.); 240824@studenti.unimore.it (M.B.); \\ malorgioilaria.94@gmail.com (I.M.); davide.tagliazucchi@unimore.it (D.T.) \\ 2 Consorzio del Formaggio Parmigiano Reggiano, Via J.F. Kennedy 18, 42124 Reggio Emilia, Italy; \\ pizzamiglio@parmigianoreggiano.it \\ * Correspondence: lisa.solieri@unimore.it; Tel.: +39-0522-522026
}

\section{check for}

updates

Citation: Martini, S.; Bonazzi, M.; Malorgio, I.; Pizzamiglio, V.;

Tagliazucchi, D.; Solieri, L.

Characterization of Yeasts Isolated

from Parmigiano Reggiano Cheese

Natural Whey Starter: From Spoilage Agents to Potential Cell Factories for Whey Valorization. Microorganisms 2021, 9, 2288. https://doi.org/ 10.3390/microorganisms 9112288

Academic Editor: Salam A. Ibrahim

Received: 10 September 2021

Accepted: 29 October 2021

Published: 3 November 2021

Publisher's Note: MDPI stays neutral with regard to jurisdictional claims in published maps and institutional affiliations.

Copyright: (c) 2021 by the authors. Licensee MDPI, Basel, Switzerland. This article is an open access article distributed under the terms and conditions of the Creative Commons Attribution (CC BY) license (https:/ / creativecommons.org/licenses/by/ $4.0 /)$.

\begin{abstract}
Whey is the main byproduct of the dairy industry and contains sugars (lactose) and proteins (especially serum proteins and, at lesser extent, residual caseins), which can be valorized by the fermentative action of yeasts. In the present study, we characterized the spoilage yeast population inhabiting natural whey starter (NWS), the undefined starter culture of thermophilic lactic acid bacteria used in Parmigiano Reggiano (PR) cheesemaking, and evaluated thermotolerance, mating type, and the aptitude to produce ethanol and bioactive peptides from whey lactose and proteins, respectively, in a selected pool of strains. PCR-RFLP assay of ribosomal ITS regions and phylogenetic analysis of 26S rDNA D1/D2 domains showed that PR NWS yeast population consists of the well-documented Kluyveromyces marxianus, as well as of other species (Saccharomyces cerevisiae, Wickerhamiella pararugosa, and Torulaspora delbrueckii), with multiple biotypes scored within each species as demonstrated by (GTG) $)_{5}$-based MSP-PCR. Haploid and diploid K. marxianus strains were identified through MAT genotyping, while thermotolerance assay allowed the selection of strains suitable to grow up to $48^{\circ} \mathrm{C}$. In whey fermentation trials, one thermotolerant strain was suitable to release ethanol with a fermentation efficiency of $86.5 \%$, while another candidate was able to produce the highest amounts of both ethanol and bioactive peptides with potentially anti-hypertensive function. The present work demonstrated that PR NWS is a reservoir of ethanol and bioactive peptides producer yeasts, which can be exploited to valorize whey, in agreement with the principles of circularity and sustainability.
\end{abstract}

Keywords: Parmigiano Reggiano cheese; whey; natural whey starter; ethanol; bioactive peptides; yeasts; Kluyveromyces marxianus; Wickerhamiella pararugosa; Torulaspora delbrueckii

\section{Introduction}

In a hungry world where the human population continues to rise and biological resources are limited, food byproduct valorization can contribute to provide sustainable solutions to the increasing food demand [1]. According to Ellen MacArthur Foundation's butterfly diagram [2], food waste and byproduct valorization can also positively impact the environment by reducing greenhouse gas emissions [3].

The dairy industry is a leader in the European food industry, and it is the secondlargest sector of food waste generation. Whey is the liquid residue resulting from the removal of the high molecular weight milk proteins, such as caseins, during the production of cheese and other dairy products [4]. Whey is the most important byproduct of cheesemaking as it represents $85-90 \%$ of the original milk volume [5]. It is estimated that 9 million tons of cheese is produced within the EU per annum. This generates around 50 million 
$\mathrm{m}^{3}$ of whey [6]. The high content of lactose (44-46 g/L) and residual proteins, especially low molecular proteins (2.5-10 g/L based on the kind of whey), increase chemical (from $60-80 \mathrm{~g} / \mathrm{L}$ ) and biological (30-50 g/L) oxygen demand values (BOD and COD, respectively) other than the limits established by national and international standards and make whey disposal in the environment very expensive. On the other hand, lactose and proteins represent potential reusable substances Traditionally whey has been used for animal feeding and ricotta cheese production. Recently, in agreement with sustainability and circularity principles, novel attempts were made to convert whey into value-added bioproducts. Whey is used to produce protein powders by spray-drying for infant nutrition, sport formulas and food additives, leaving the lactose rich liquid, called whey permeate, for environmental disposal. Several other bio-products can be produced from whey and whey permeate, such as bioethanol [7], biohydrogen [8,9], prebiotics [10], bacteriocin [11,12], biopolymer [13], and exopolysaccharides [14]. Additionally, whey permeate has been investigated as cheap medium to produce single cell proteins $[15,16]$ and to propagate either probiotics or other industrially significant cell factories [17]. More recent efforts demonstrated that whey can be a source of bioactive compounds such as bioactive peptides, which can be released from whey proteins by the action of either enzymes or microbes [5,18-21]. Bioactive peptides are defined as specific protein fragments that positively impact body functions and can promote good health and the prevention of diseases [22]. Whey drink or whey protein hydrolysates enriched in bioactive peptides can valorize the whey, creating value-added products that may promote human health. Integration of these solutions in a rationale frameshift for valorizing different whey components is called the whey biorefinery concept [23].

Many of the attempts for whey valorization entail the use of microbes as cell factories for catalyzing whey bioprocessing. Among them, non-conventional yeasts alternative to the well-known model organism Saccharomyces cerevisiae, are attracting increasing interest to create value-added products from food waste thanks to their ability to ferment alternative sugars other than glucose and to survive under multiple stressors better than S. cerevisiae [24]. Consequently, different naturally fermented foods and environmental niches have been exploited as reservoirs of wild non-conventional yeasts.

Parmigiano Reggiano (PR) is an Italian protected designation of origin (PDO) hard and cooked cheese made from raw partly skimmed cow's milk supplemented with natural whey starter $[25,26]$. Natural whey starter (NWS) is an undefined consortium of thermophilic lactic acid bacteria (LAB) obtained by incubation of the previous day residual acidic whey at a gradually decreasing temperature after the curd heating [27-29]. Obligate homofermentative LAB belonging to Lactobacillus helveticus, Streptococcus thermophilus, and Lactobacillus delbrueckii (especially subspecies lactis) and the heterofermentative species Limosilactobacillus fermentum dominate the NWS microbiota and are responsible for fast milk acidification and casein precipitation together with the calf rennet. Additionally, lactose-fermenting yeasts can contaminate NSW and co-exist with starter LAB [30]. In PR NWS Kluyveromyces marxianus was the dominant yeast species [30,31]. This food-grade yeast is an emerging cell factory proposed as bioethanol producer [32], probiotic agent [33], and enzyme-producer [34].

In this study, we explored yeast biodiversity of PR NWS and evaluated yeast candidates to produce ethanol and to release bioactive peptides from whey proteins during whey fermentation. We demonstrated that yeasts from PR NWS are not only spoilage agents but also beneficial cell factories exploitable for ethanol production and development of whey protein hydrolysates and whey fermented drink enriched in bioactive peptides.

\section{Materials and Methods}

\subsection{Chemicals and Reference Strains}

All chemicals and media were purchased from Sigma Aldrich (St. Louis, MO, USA), except where differently indicated. Oligonucleotides were from Bio-Fab Research (Rome, Italy). Kluyveromyces marxianus CBS608 was used as reference MATa/MAT $\alpha$ strain and cultivated in YPDA ( $1 \% w / v$ yeast extract, $2 \% w / v$ peptone, $2 \% w / v$ dextrose, and $2 \% w / v$ agar) medium. 


\subsection{Sampling, Physicochemical and Microbiological Analyses}

NWS samples were obtained from three different PR cheese dairies located in the PDO cheese production area (Reggio Emilia, Italy). Fifty milliliters of NWS were collected in duplicates in sterile flasks just before the addition to the vat milk (a mixture of morning milk and partially skimmed evening milk). Samples were shipped to the laboratory under refrigerated conditions and immediately submitted to physicochemical and microbiological determinations. Titratable acidity was determined using the Soxhlet-Henkel method with $0.25 \mathrm{~N} \mathrm{NaOH}$ [35]. The $\mathrm{pH}$ was determined at samples temperature of $25^{\circ} \mathrm{C}$ after calibration of $\mathrm{pH}$ meter (Crison Instruments, Barcelona, Spain) at the same temperature. Lactic acid bacteria counts were determined by fluorocytometry with a Bactoscan 8000 apparatus (Foss Electric, Hillerød, Denmark) and expressed as $\log _{10} \mathrm{CFU} / \mathrm{mL}$ values.

Yeast counts were determined by plating ten-fold diluted NWS samples on YPDA and YPLA ( $1 \% w / v$ yeast extract, $2 \% w / v$ peptone, $2 \% w / v$ lactose, and $2 \% w / v$ agar) media through spreading method. To inhibit bacterial growth, both media were supplemented with $100 \mathrm{mg} / \mathrm{L}$ chloramphenicol. The YPDA and YPLA plates were incubated at $28^{\circ} \mathrm{C}$ and $42{ }^{\circ} \mathrm{C}$ for $48-72 \mathrm{~h}$, respectively, as previously reported [31]. Analyses were carried out in triplicate. Yeast population was expressed as mean of $\log _{10} \mathrm{CFU} / \mathrm{mL}$ values. At least $10 \%$ of colonies recovered from $20-200 \mathrm{CFU} / \mathrm{mL}$ plates were randomly selected from each medium and purified by streaking at least two times onto the same medium. Purified isolates were maintained at $4{ }^{\circ} \mathrm{C}$ on YPDA slants and stored at $-80^{\circ} \mathrm{C}$ in the YPD broth medium supplemented with $25 \%(w / v)$ glycerol as cryopreservation agent.

\subsection{DNA Extraction, Molecular Caracterization, and Phylogenetic Analysis}

For DNA isolation, pure cultures of yeasts were grown in YPD broth at $28{ }^{\circ} \mathrm{C}$ for $48 \mathrm{~h}$. Genomic DNA (gDNA) was extracted as reported by Hoffman and Winston [36]. The final quantity of the resultant DNA was determined by NanoDrop ND-1000 device (Thermo Scientific Waltman, MA, USA) and diluted to $50 \mathrm{ng} / \mu \mathrm{L}$ with sterile ultra-pure water. Template DNA samples were stored at $-20^{\circ} \mathrm{C}$ till used.

PCR amplification of ITS regions was carried out with the primers ITS1 (5'-TCCGTAGG TGAACCTGCGG-3') and ITS4 (5'-TCCTCCGCTTATTGATATGC-3') [37] in a reaction mixture (final volume $40 \mu \mathrm{L}$ ) containing 1X Dream Taq Green Buffer (Thermo Scientific Waltman, MA, USA), $1.5 \mathrm{mM} \mathrm{MgCl} 2,0.2 \mathrm{mM}$ of each dNTPs (Thermo Scientific Waltman, MA, USA), $0.5 \mu \mathrm{M}$ of each primer, $0.5 \mathrm{U}$ of DreamTaq DNA polymerase (Thermo Scientific Waltman, MA, USA) and 50 ng of gDNA. Thermal conditions consisted of $94{ }^{\circ} \mathrm{C}$ initial denaturation for $1 \mathrm{~min} ; 35$ amplification cycles of $1 \mathrm{~min}$ at $94{ }^{\circ} \mathrm{C}, 2 \mathrm{~min}$ at $55^{\circ} \mathrm{C}, 2 \mathrm{~min}$ at $72{ }^{\circ} \mathrm{C}$; final extension at $72{ }^{\circ} \mathrm{C}$ for $10 \mathrm{~min}$.

PCR amplification of the D1/D2 domains of the 26S rRNA gene (LSU) was carried out with the primers NL-1 (5'-GCATATCAATAAGCGGAGGAAAAG-3') and NL4 (5'-GGTCCGTGTTTCAAGACGG-3') [38] using rTAq DNA polymerase under the same reaction conditions reported for ITS region. Thermal cycling included initial denaturation at $94{ }^{\circ} \mathrm{C}$ for $5 \mathrm{~min}$; 36 cycles of $94{ }^{\circ} \mathrm{C}$ for $1 \mathrm{~min}, 52{ }^{\circ} \mathrm{C}$ for $45 \mathrm{~s}, 72{ }^{\circ} \mathrm{C}$ for $2 \mathrm{~min}$; final extension at $72{ }^{\circ} \mathrm{C}$ for $10 \mathrm{~min}$, followed by cooling at $4{ }^{\circ} \mathrm{C}$.

All PCR reactions were carried out in a T100 thermal cycler (Bio-Rad, Hercules, CA, USA). The presence of amplicons was confirmed by electrophoresis in $1.2 \%(w / v)$ agarose gel in $0.5 \times$ TBE ( $89 \mathrm{mM}$ Tris-borate, $2 \mathrm{mM}$ EDTA, $\mathrm{pH}$ 8) buffer and stained with $0.5 \mu \mathrm{g} / \mathrm{mL}$ of ethidium bromide. All gels were visualized by UV and captured as TIFF format files by in a gel documentation system (BioDocAnalyze, Biometra, Göttingen, Germany).

ITS amplicons were subjected to restriction fragment length polymorphism (RFLP) analysis using endonucleases HaeIII and HinfI (Thermo Scientific, Waltman, MA, USA), according to manufacturer's instructions. The resulting restriction fragments were separated by $2.0 \%(w / v)$ agarose gel electrophoresis in $0.5 \times$ TBE buffer at $70 \mathrm{~V}$ for $2 \mathrm{~h}$. PCR amplicons and restriction profiles were compared to those present in the Yeast-ID database (www.yeast-id.org, accessed on 9 September 2021) with rank parameter at $\pm 20 \mathrm{bp}$. 
PCR amplicons of 26S rDNA D1/D2 domains were purified using DNA Clean \& Concentrator ${ }^{\mathrm{TM}}-5 \mathrm{Kit}$ (Zymo Research, Orange, CA, USA) and sequenced on both strands using NL1 and NL4 primers through a DNA Sanger dideoxy sequencing process performed by Bio-Fab Research (Rome, Italy). Consensus sequences were merged using the program SeqMan (DNASTAR, Madison, WI, USA) and the poor-quality ends were edited manually to remove primers. The nucleotide sequences were compared with sequences available in the NCBI (www.ncbi.nih.gov; last access on 3 September 2021). Strains with 0-3 nucleotide differences in the D1/D2 domain were treated as conspecific, while strains showing greater than $1 \%$ nucleotide substitutions were considered to belong to different species [38]. The related sequences were aligned with Muscle program [39] in MEGA X software [40] and the resulting alignment was subjected to a DNA substitution model analysis to select the bestfitting model. Phylogenetic relationships were inferred using the Kimura 2-parameter (K2P) model and the neighbor joining (NJ) method. Among sites rate variation was modelled by a gamma distribution $(+G)$. Bootstrap support values were obtained from 1000 random resamplings. Tree was visualized using Interactive Tree of Life (ITOL) [41] and rooted at outgroup reference strains. The sequences obtained in this study were deposited in the GenBank NCBI database with the accession numbers MZ491084-MZ491094.

\subsection{Genotyping}

Intraspecific diversity of isolates was assessed by microsatellite-primed PCR (MSPPCR) using the primer (GTG) 5 (5'-GTGGTGGTGGTGGTG-3'), as previously reported [42]. PCR products were separated by $1.8 \%(w / v)$ gel electrophoresis in $0.5 \times$ TBE buffer for $7 \mathrm{~h}$ under constant $70 \mathrm{~V}$ under refrigerated conditions. The GeneRuler $100 \mathrm{bp}$ Plus DNA Ladder (ThermoScientific, Waltman, MA, USA) served as a molecular size marker. All DNA fingerprint digital images were captured in Tiff format as reported above and processed by the BioNumerics software version 3.0 (Applied Maths, Sint-Martens-Latem, Belgium). Band assignment was manually curated after automatic band detection. Bands patterns similarities were calculated using the Pearson's correlation similarity coefficient. Optimization value and curve smoothening were set at $0.5 \%$. Dendrograms were constructed by the unweighted-pair group method using the arithmetic means (UPGMA) clustering method. Isolates of $\geq 92 \%$ similarity were treated as a single strain.

\subsection{MAT Genotyping of Kluyveromyces marxianus Strains}

MAT genotyping was carried out with the primers SLA2 (5'-TATACATGGGATCATA AATC-3 ${ }^{\prime}$ ) [43], MATa1D (5'-GGTTTGGCAGGAGTACAACTA-3'), and MATa1D (5'-TGAAA TCCAAAGCACCAACT-3') [44]. PCR reactions were performed in a final volume of $20 \mu \mathrm{L}$ containing 1X Green Buffer (Thermo Scientific, Waltman, MA, USA); $200 \mu \mathrm{M}$ dNTPs (Thermo Scientific, Waltman, MA, USA), $0.5 \mu \mathrm{M}$ each primer, 0.5 U Dream Taq DNA polymerase (Thermo Scientific, Waltman, MA, USA) and $50 \mathrm{ng}$ of gDNA. PCR amplification was performed on a MyCycler TM thermal cycler (BioRad, Hercules, CA) with an initial denaturation at $95^{\circ} \mathrm{C}$ for $3 \mathrm{~min}$, followed by 10 cycles consisting of $30 \mathrm{~s}$ at $95^{\circ} \mathrm{C}, 45 \mathrm{~s}$ at $53{ }^{\circ} \mathrm{C}$ and $3 \mathrm{~min}$ at $72{ }^{\circ} \mathrm{C}$, and 25 cycles consisting of $30 \mathrm{~s}$ at $95^{\circ} \mathrm{C}, 45 \mathrm{~s}$ at $55^{\circ} \mathrm{C}$ and $3 \mathrm{~min}$ at $72{ }^{\circ} \mathrm{C}$, and a final extension of $10 \mathrm{~min}$ at $72{ }^{\circ} \mathrm{C}$. A single primer test was done to exclude any unspecific amplifications. PCR products were separated by $1.5 \%(w / v)$ agarose gel electrophoresis in $0.5 \mathrm{X}$ TBE buffer for $4 \mathrm{~h}$ at $70 \mathrm{~V}$. DNA fragment size was estimated using Gene Ruler $^{\mathrm{TM}} 1 \mathrm{~kb}$ Plus DNA ladder (Thermo Scientific, Waltham, MA). Expected sizes were 2620 and $2863 \mathrm{bp}$ for MATa and MAT $\alpha$ amplicons, respectively [44].

\subsection{Thermotolerance Assay}

The ability to grow at 42,45 and $48{ }^{\circ} \mathrm{C}$ was tested as previously reported [45]. Briefly, four ten-fold dilutions from $10^{2}$ to $10^{5} \mathrm{cell} / \mathrm{mL}$ were prepared from overnight grown cultures of each yeast cultures $\left(27^{\circ} \mathrm{C}\right.$ in $5 \mathrm{~mL}$ of YPD broth). Five microliters of cell suspensions were spotted onto YPDA agar plates pre-adapted to the appropriate temperature. Plates 
were sealed with Parafilm and incubated for 5 days at the appropriate temperature. Plates incubated at $27^{\circ} \mathrm{C}$ were used as positive control. Assays were performed in duplicates.

\subsection{Whey Fermentation Assays}

The assays were done according to Tofalo et al. [46] with a few modifications. Briefly, yeast strains grown overnight at $28^{\circ} \mathrm{C}$ in $30 \mathrm{~mL}$ YPD medium were inoculated into $100 \mathrm{~mL}$ bottles filled with $50 \mathrm{~mL}$ of pasteurized $\left(95^{\circ} \mathrm{C}\right.$ for $\left.10 \mathrm{~min}\right)$ cow acidic whey $(5.67 \% \mathrm{w} / \mathrm{v} \pm 0.06$ lactose, $0.05 \% w / v \pm 0.02$ glucose, $0.65 \% w / v \pm 0.03$ galactose and $9.5 \% w / v \pm 0.1$ lactic acid; $\mathrm{pH} 4.80 \pm 0.07)$ at the final concentration of $5 \times 10^{7} \mathrm{CFU} / \mathrm{mL}$. Inoculated whey was overlaid with $10 \mathrm{~mL}$ of paraffin oil and fermentation was carried out at $30{ }^{\circ} \mathrm{C}$. Non inoculated whey was used as negative control. Weight loss of the flasks due to $\mathrm{CO}_{2}$ release was measured with an analytical balance and used to monitor fermentation progress. Fermentation trials were stopped after 14 days, and supernatants were collected by centrifugation at 14,000 rpm for $20 \mathrm{~min}$ at $4{ }^{\circ} \mathrm{C}$ and then stored at $-20^{\circ} \mathrm{C}$ until further analysis. Lactose consumption and ethanol production were enzymatically assessed (Megazyme Bray, Ireland).

\subsection{Proteolysis Degree and Peptidomic Analysis by Ultra High Performance Liquid Chromatography/High Resolution Mass Spectrometry (UHPLC/HR-MS)}

Proteolysis degree was determined in the supernatants obtained from the whey fermentation trials, by the 2,4,6-trinitrobenzenesulphonic acid (TNBS) method [47]. The results were expressed as $\mathrm{mmol} / \mathrm{L}$ of leucine equivalents. All the analyses were carried out in duplicates.

Low molecular weight peptides released in the supernatants collected from the whey fermentation experiments were separated through a C18 column (Acquity UPLC HSS C18 Reversed phase, $2.1 \times 100 \mathrm{~mm}, 1.8 \mu \mathrm{m}$ particle size, Waters, Milan, Italy) by using a UHPLC system (UHPLC Ultimate 3000 separation module, Thermo Scientific, San Jose, CA, USA) and analyzed by a Q Exactive Hybrid Quadrupole-Orbitrap Mass Spectrometer (Thermo Scientific, San Jose, CA, USA). The full description of the chromatographic conditions, mass spectrometry and tandem mass spectrometry parameters was reported in Martini et al. [48].

Peptide sequencing was carried out by using MASCOT (Matrix Science, Boston, MA, USA) protein identification software as fully described in Martini et al. [48]. The full lists of identified peptides were submitted to the Milk Bioactive Peptides Database (MBPDB) to identify peptides with $100 \%$ homology to previously demonstrated bioactive peptides [49].

\subsection{Statistical Analysis}

All data were presented as mean \pm standard deviation (SD) for three replicates for each sample. The growth kinetics of yeasts in whey were calculated with Grofit package implemented in R [50]. Two-way ANOVA with Bonferroni post-test were performed using Graph Pad Prism (GraphPad Software, San Diego, CA, USA). The differences were considered significant with $p$ value $<0.05$.

\section{Results}

\subsection{Physicochemical Analysis and Microbiological Counts}

Physicochemical parameters and microbiological counts of NWS samples were reported in Table 1. Yeast population ranged from 2.03 to $3.43 \log _{10}$ CFU/mL in R_NWS and L_NWS samples, respectively. Except for R_NWS, no significant differences in yeast counts were detected between culture conditions. Sample L_NWS showed higher yeast population than R_NWS and C_NWS $(p<0.05)$. Titratable acidity measured as SH degree of L_NWS was intermediated between R_NWS and C_NWS, while pH value in L_NWS was higher than those found in samples R_NWS and C_NWS $(p<0.05)$.

\subsection{Yeast Molecular Characterization and Species Assignment}

Ninety-one isolates retrieved from YPDA and YPLA media at 28 and $42{ }^{\circ} \mathrm{C}$, respectively, were submitted to PCR-RFLP analysis of ITS regions with the endonucleases HaeIII and HinfI. We identified 4 restriction patterns, referred to as A to D (Table 2). Search in Yeast-ID database 
was carried out for a first tentative species attribution. Pattern A matched Kluyveromyces dobzhanskii (100\% matching), followed by K. marxianus ( $94 \%$ matching), while patterns B and D matched S. cerevisiae and Torulaspora delbrueckii profiles (100\% matching), respectively. Pattern C was shared by five Candida spp., including Candida incommunis, Candida pararugosa (current name Wickerhamiella pararugosa), Candida pseudointermedia, Candida intermedia, Candida catenulata (current name Diutina catenulata), and Candida diversa (current name Saturnispora diversa).

Table 1. Physicochemical and microbiological parameters of NWS samples. Values (Log10 CFU/mL) are means $\pm S D$ of three replicates $(n=3)$.

\begin{tabular}{|c|c|c|c|c|c|}
\hline \multirow{2}{*}{ Sample } & \multirow{2}{*}{$\mathrm{pH}$} & \multirow[b]{2}{*}{ SH } & \multirow{2}{*}{$\begin{array}{c}\text { LAB Count } \\
\left(\log _{10}\right. \\
\text { CFU/mL) }\end{array}$} & \multicolumn{2}{|c|}{ Yeast Counts $\left(\log _{10} \mathrm{CFU} / \mathrm{mL}\right)$} \\
\hline & & & & YPDA $28^{\circ} \mathrm{C}$ & YPLA $42{ }^{\circ} \mathrm{C}$ \\
\hline R_NWS & $3.29 \pm 0.01^{\mathrm{a}}$ & $31.01 \pm 0.02^{\mathrm{a}}$ & $8.65 \pm 0.01^{\mathrm{a}}$ & $2.45 \pm 0.11^{a, *}$ & $2.03 \pm 0.06^{\mathrm{a}, *}$ \\
\hline C_NWS & $3.27 \pm 0.00^{\mathrm{a}}$ & $31.41 \pm 0.01^{\mathrm{c}}$ & $8.71 \pm 0.01^{b}$ & $2.74 \pm 0.04^{\mathrm{a}}$ & $2.84 \pm 0.06^{\mathrm{a}}$ \\
\hline L_NWS & $3.44 \pm 0.00^{b}$ & $31.37 \pm 0.01^{b}$ & $8.72 \pm 0.01^{b}$ & $3.43 \pm 0.32^{b}$ & $3.41 \pm 0.21^{b}$ \\
\hline
\end{tabular}

Values within a column with different superscript letters are significantly different $(p<0.05)$. Asterisks, when present, indicate significant differences between growth conditions (between columns) $(p<0.05)$.

Table 2. Isolation source and ITS restriction patterns of PR NWS yeast isolates. Tentative yeast identification was obtaining by using ITS restriction patterns as queries in Yeast ID databases (www.yeast-id.org; last accessed on 9 September 2021).

\begin{tabular}{|c|c|c|c|c|c|c|c|}
\hline \multirow{2}{*}{ Sample } & \multirow{2}{*}{$\begin{array}{l}\text { Growth } \\
\text { Conditions }\end{array}$} & \multirow{2}{*}{ Strains } & \multirow{2}{*}{ Amp (bp) } & \multicolumn{2}{|c|}{ Restriction Fragments } & \multirow{2}{*}{ Yeast ID Best Matches } & \multirow{2}{*}{ Pattern } \\
\hline & & & & HaeIII & Hinf I & & \\
\hline \multirow{5}{*}{ R_NWS } & YPDA, $28^{\circ} \mathrm{C}$ & $\begin{array}{c}\text { RO101 RO102 RO103 RO104 } \\
\text { RO105 RO106 RO107 RO108 } \\
\text { RO109 }\end{array}$ & 740 & $655-80$ & $240-185-120-80$ & $\begin{array}{l}\text { K. dobzhanskii }(100 \%) / \\
\text { K. marxianus }(94 \%)\end{array}$ & $\mathrm{A}$ \\
\hline & \multirow[t]{4}{*}{ YPLA $42{ }^{\circ} \mathrm{C}$} & $\begin{array}{c}\text { RO202 RO205 RO207 RO208 } \\
\text { RO209 }\end{array}$ & 740 & $655-80$ & $240-185-120-80$ & $\begin{array}{l}\text { K. dobzhanskii }(100 \%) / \\
\text { K. marxianus }(94 \%)\end{array}$ & A \\
\hline & & RO201 & 850 & $325-230-170-125$ & $375-365-110$ & S. cerevisiae $(100 \%)$ & $\mathrm{B}$ \\
\hline & & RO203 & 420 & 420 & $200-220$ & Candida spp. $(100 \%)$ & $\mathrm{C}$ \\
\hline & & RO204-1 RO204-2 & 800 & 800 & $425-400$ & T. delbrueckii $(100 \%)$ & $\mathrm{D}$ \\
\hline \multirow{4}{*}{ C_NWS } & \multirow[t]{2}{*}{ YPDA, $28^{\circ} \mathrm{C}$} & $\begin{array}{l}\text { CA101 CA103 CA104 CA105 } \\
\text { CA107 CA108 CA109 } \text { CA110 } \\
\text { CA111 CA112 CA113 CA114 } \\
\text { CA115 CA116 CA117 CA118 }\end{array}$ & 740 & $655-80$ & $240-185-120-80$ & $\begin{array}{c}\text { Kluyveromyces } \\
\text { dobzhanskii }(100 \%) / \\
\text { Kluyveromyces marxianus } \\
(94 \%)\end{array}$ & A \\
\hline & & CA102 CA106 & 850 & $325-230-170-125$ & $375-365-110$ & S. cerevisiae $(100 \%)$ & $\mathrm{B}$ \\
\hline & \multirow[t]{2}{*}{ YPLA $42{ }^{\circ} \mathrm{C}$} & $\begin{array}{l}\text { CA201 CA202 CA203 CA204 } \\
\text { CA205 CA207 CA208 CA209 } \\
\text { CA210 CA211 CA212 CA213 } \\
\text { CA214 CA215 CA216 CA217 } \\
\text { CA218 }\end{array}$ & 740 & $655-80$ & $240-185-120-80$ & $\begin{array}{l}\text { K. dobzhanskii }(100 \%) / \\
\text { K. marxianus }(94 \%)\end{array}$ & A \\
\hline & & CA206 & 850 & $325-230-170-125$ & $375-365-110$ & S. cerevisiae $(100 \%)$ & $\mathrm{B}$ \\
\hline \multirow{6}{*}{ L_NWS } & \multirow[t]{3}{*}{ YPDA, $28^{\circ} \mathrm{C}$} & $\underline{\text { LA102 LA110 LA112 }}$ & 740 & $655-80$ & $240-185-120-80$ & $\begin{array}{l}\text { K. dobzhanskii }(100 \%) / \\
\text { K. marxianus }(94 \%)\end{array}$ & A \\
\hline & & LA101 LA103 LA111 & 850 & $325-230-170-125$ & $375-365-110$ & S. cerevisiae $(100 \%)$ & B \\
\hline & & $\begin{array}{l}\text { LA104 LA105 LA106 LA107 } \\
\text { LA108 LA109 LA113 LA114 } \\
\text { LA115 LA116 LA117 LA118 }\end{array}$ & 420 & 420 & $200-220$ & Candida spp. $(100 \%)$ & $\mathrm{C}$ \\
\hline & \multirow[t]{3}{*}{ YPLA $42{ }^{\circ} \mathrm{C}$} & $\begin{array}{l}\text { LA201 LA202 LA203 LA210 } \\
\text { LA211 LA212 }\end{array}$ & 740 & $655-80$ & $240-185-120-80$ & $\begin{array}{l}\text { K. dobzhanskii }(100 \%) / \\
\text { K. marxianus }(94 \%)\end{array}$ & $\mathrm{A}$ \\
\hline & & LA207 LA208 LA209 LA214 & 850 & $325-230-170-125$ & $375-365-110$ & S. cerevisiae $(100 \%)$ & $\mathrm{B}$ \\
\hline & & $\begin{array}{l}\text { LA204 LA205 LA206 LA213 } \\
\text { LA215 LA216 LA217 LA218 }\end{array}$ & 420 & 420 & $200-220$ & Candida spp. $(100 \%)$ & $\mathrm{C}$ \\
\hline
\end{tabular}

Strains in bold were submitted to sequencing of 26S rDNA D1/D2 domain, while underlined strains were screened for whey fermentation. All the fragment sizes are in bp. Fragments lower than $70 \mathrm{bp}$ were omitted from the analysis. Abbreviation: Amp, amplicon length.

To assist the species identification by ITS PCR-RFLP, representative strains for each restriction pattern were submitted to sequencing of D1/D2 domain of 26S rRNA gene. A total of 11 sequences were submitted to BLASTn search against Refseq database to identify the closest relatives of the sequenced strains. A dataset of 33 sequences were built, aligned and phylogenetic relationships were inferred by NJ method. As shown in Figure 1, the sequences were resolved into four distinct clades. Strains RO201 and CA102 placed into 
Saccharomyces clade and formed a monophyletic group with S. cerevisiae NRRL Y-12632, in agreement with ITS PCR-RFLP analysis. Therefore, they were identified as $S$. cerevisiae. The sequences of strains representatives of pattern A aligned closely with those of K. marxianus strains CBS 712 and NRRL Y-8281, while strain RO204_3 grouped together with the type strain of T. delbrueckii with robust support. These results agreed with those found by ITS PCR-RFLP analysis. Finally, phylogenetic analysis identified strains with restriction pattern C as W. pararugosa. However, strains LA118 and LA206 showed 6 SNPs compared to $W$. pararugosa CBS 1010 (98.94\% identity) (Supplementary Figure S1). Analyses with additional molecular barcodes are required to further investigate taxonomic position of these strains.

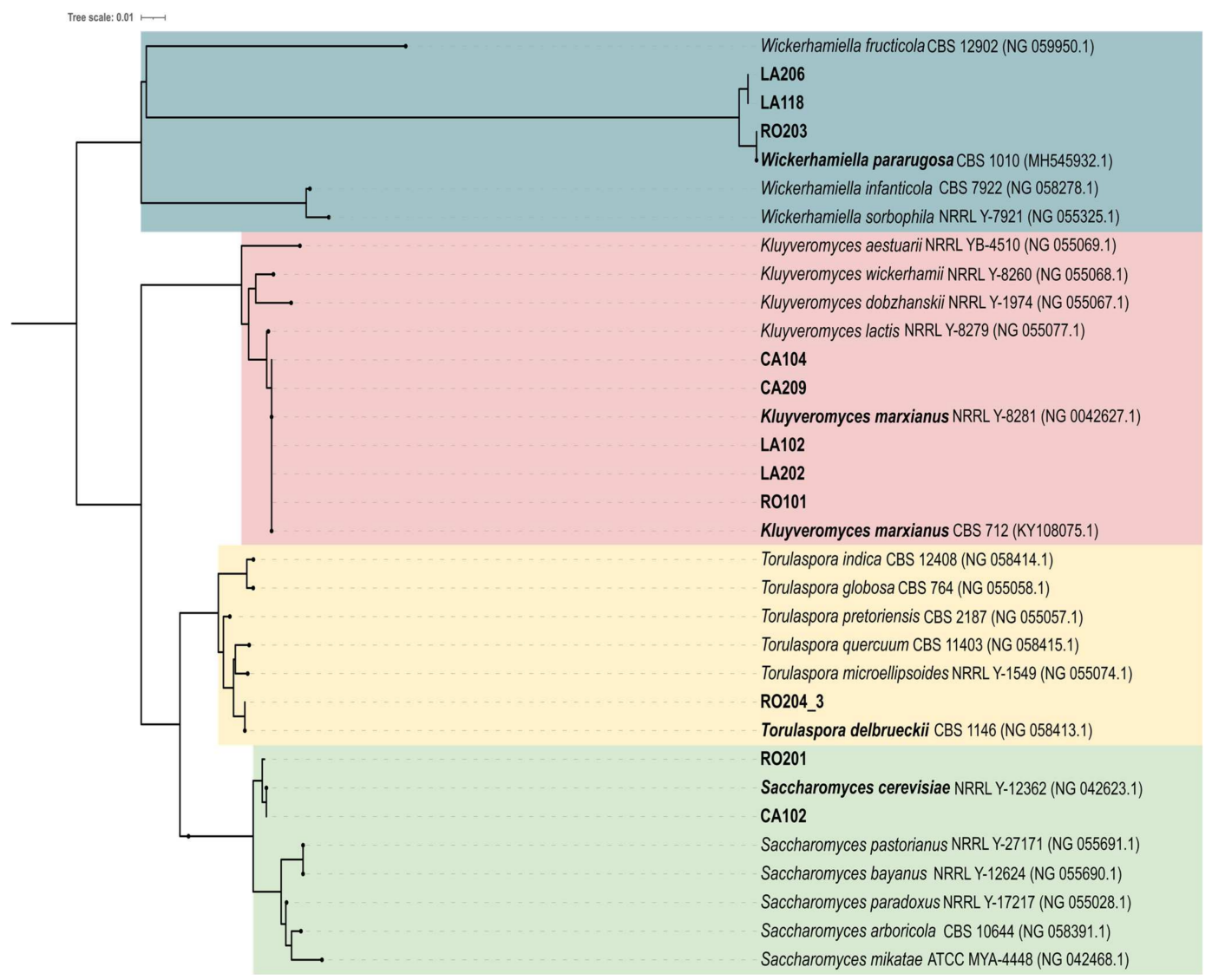

Figure 1. The neighbor joining (NJ) tree inferred from the dataset containing the $3326 \mathrm{~S}$ rRNA D1/D2 nucleotide sequences. The GenBank accession numbers were reported in the brackets. PR NWS yeast strains are reported in bold. The evolutionary distances were computed using the Kimura 2-parameter method and are in the units of the number of base substitutions per site. The rate variation among sites was modeled with a gamma distribution. Branch lengths are proportional to the numbers of nucleotide substitutions and are measured by the scale bar of sequence divergence.

\subsection{Yeast Diversity and Species Distribution}

PCR-fingerprinting with primer (GTG) $)_{5}$ was carried out to assess genetic diversity of 82NWS isolates, including 3 T. delbrueckii, 3 S. cerevisiae, 55 K. marxianus, and 21 W. pararugosa strains. Complex fingerprinting patterns consisted of 5 to 11 fragments with size from 442 to $2884 \mathrm{bp}$ (Figure 2). The UPGMA dendrogram created using Pearson similarity coefficient grouped strains into two major clusters with a similarity level of $26.3 \%$. Major cluster I grouped S. cerevisiae and T. delbrueckii strains, while major cluster II the K. marxianus and W. pararugosa strains. S. cerevisiae and T. delbrueckii strains branched at similarity level of $32.4 \%$ within cluster I, while most of $W$. pararugosa strains clustered separately from K. marxianus strains. Application of a similarity threshold of $92 \%$ as reproducibility cut-off allowed the identification of 12 different genotypes and 10 singletons (Figure 2). Most of the isolates clustered congruently with the dairy provenience, species attribution and isolation conditions. 
Except for LA218 and RO203, 19 W. pararugosa isolates clustered together and divided them into two different genotypes (similarity threshold of $92 \%$ ). Most of K. marxianus strains clustered together with a similarity level of $76.8 \%$. We scored five different genotypes and five singletons in this clusters. The only exceptions were K. marxianus LA102, LA110, CA111, and CA208, which branched separately into two distinct clusters. Based on the genotypes scored, a pool of $24 \mathrm{~K}$. marxianus strains was selected for subsequent functional characterization.

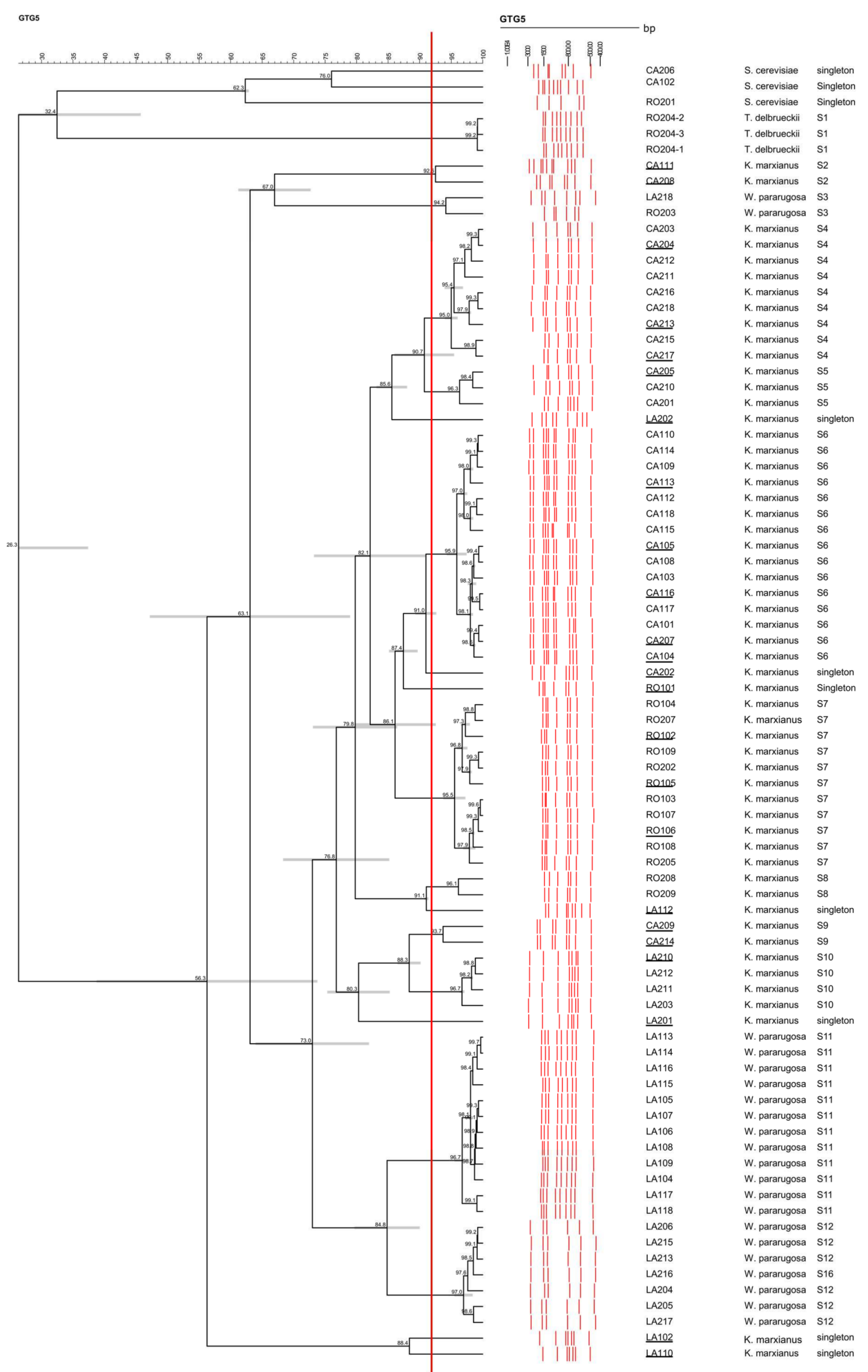

Figure 2. Tree obtained from UPGMA analysis of (GTG) $)_{5}$ MSP-PCR profiles of 82 NWS yeast isolates, using Pearson's correlation coefficient. The similarity value of $92 \%$ was used for biotype discrimination. Selected strains are reported in bold. Error bars are reported in grey at each node together with the percentage of similarity. 
Considering the strains isolated in this study, K. marxianus was the species with the highest occurrence (61.5\%), followed by W. pararugosa $(23.1 \%)$, S. cerevisiae $(12.1 \%)$ and $T$. delbrueckii (3.3\%) (Figure 3, panel A). Remarkably, W. pararugosa and T. delbrueckii have been never described in PR NWS. K. marxianus and S. cerevisiae were ubiquitous in all the samples considered, while T. delbrueckii was detected only in R_NWS (Figure 3, panel B). As expected, K. marxianus was dominant in R_NWS and C_NWS, whereas L_NWS exhibited $W$. pararugosa as dominant species. In this sample four different genotypes of $W$. pararugosa were detected. Intrastrain diversity was high also in K. marxianus populations with 3, 7, and 3 different genotypes detected in R_NWS, C_NWS, and L_NWS samples, respectively (Figure 3, panel B).

A

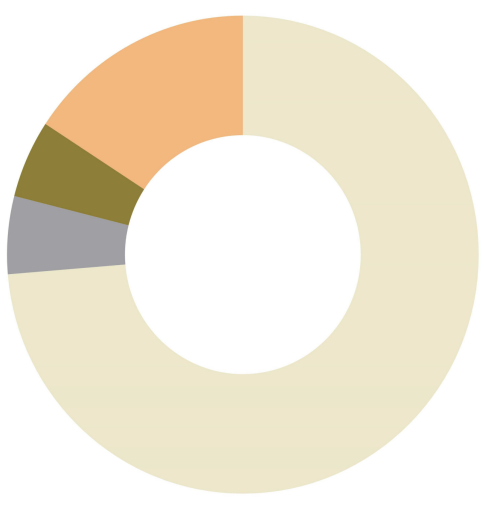

T. delbrueckii S. cerevisiae

B

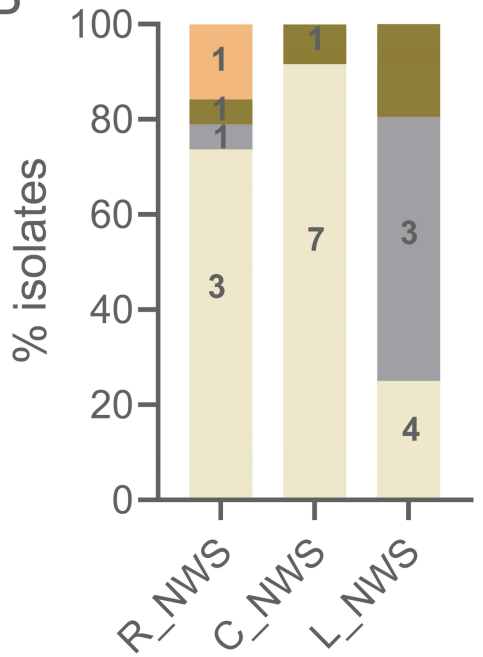

Figure 3. Yeast species frequencies and distribution in PR NSW samples. Pie-chart (panel (A)) represents yeast species frequencies, while column graph (panel (B)) species distribution in each sample. Numbers on the column represent biotypes scored by UPGMA analysis of (GTG) 5 MSP-PCR fingerprinting data.

\subsection{MAT Genotyping and Thermotollerance Assays}

The mating type defines cell identity and competence for mating (in either MATa or $M A T \alpha$ cells) and meiosis (in MATa /MAT $\alpha$ cells) [51]. Furthermore, MAT genotyping could be informative on ploidy of yeast cells, with either MATa or MAT $\alpha$ locus suggesting a haploid status, while $M A T \mathrm{a} / M A T \alpha$ supporting a diploid status. Therefore, we firstly characterized $24 \mathrm{~K}$. marxianus strains for their MAT genotype. Multiplex PCR assay targeting region across SLA2-MAT junctions (outside the $\mathrm{Z}$ regions) allowed for the discrimination of $50 \%$ of strains as MATa/MAT $\alpha, 33.33 \%$ as $M A T \alpha$, and $16.67 \%$ as MATa (Figure 4 ). The recovery of putative haploid MATa and $M A T \alpha$ isolates could be useful for future breeding programs. 


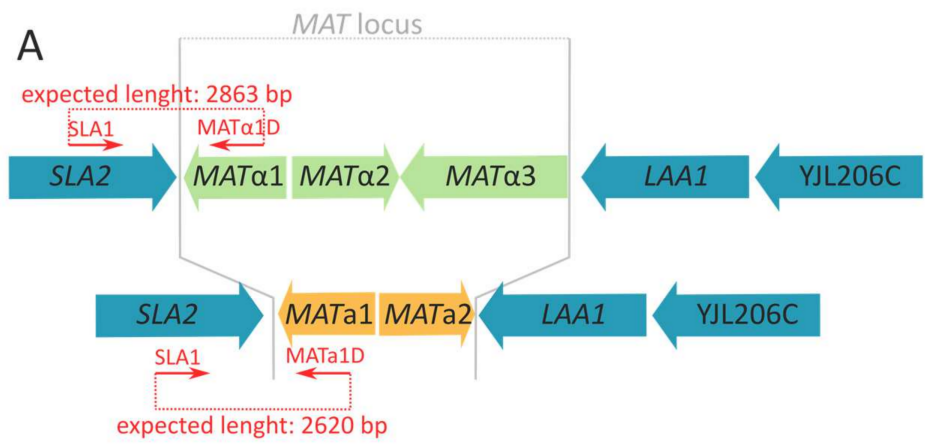

B

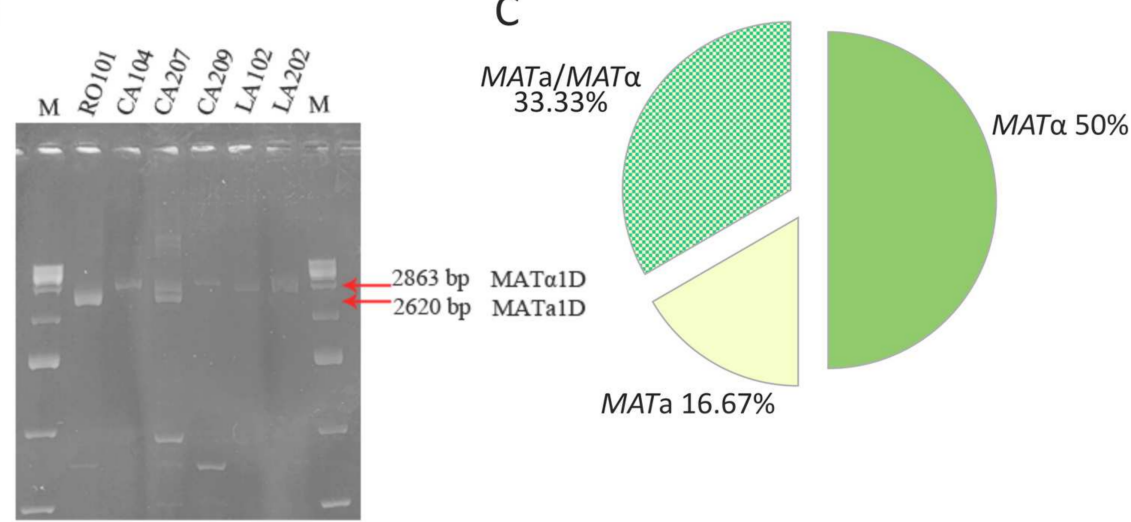

Figure 4. MAT genotyping of Kluyveromyces marxianus strains. (A) Primer sets anneal the either Ya or $\mathrm{Y} \alpha$ region in the MAT locus and the flanking gene SLA2 outside the $\mathrm{Z}$ region. PCR amplicons of different length discriminates MATa and MAT $\alpha$ loci (panel (A)). (B) An example of PCR products obtained using multiplex PCR assay targeting SLA2-MAT junctions. (C) Percentage of MAT genotypes is summarized in pie chart.

Among stressful conditions, high temperature is frequently encountered in industrial bioprocesses. Interestingly, the tolerance to high temperature is a remarkable feature in K. marxianus, which can ferment sugars into ethanol at temperature above $40{ }^{\circ} \mathrm{C}$, with some strains suitable to growth until $52{ }^{\circ} \mathrm{C}$ [52]. Therefore, we screened $24 \mathrm{~K}$. marxianus candidates for the ability to grow at 45 and $48{ }^{\circ} \mathrm{C}$. We firstly identified 13 candidates suitable to grow at $45^{\circ} \mathrm{C}$. Among them, five strains, namely CA204, CA205, CA116, LA202, and LA112, were also able to grow up to $48^{\circ} \mathrm{C}$ (Figure 5). 


\begin{tabular}{|c|c|c|c|c|c|}
\hline \multirow[b]{2}{*}{ Strains } & \multicolumn{4}{|c|}{ Temperature } & \multirow[b]{2}{*}{ Total score } \\
\hline & $27^{\circ} \mathrm{C}$ & $42^{\circ} \mathrm{C}$ & $45^{\circ} \mathrm{C}$ & $48^{\circ} \mathrm{C}$ & \\
\hline CA204 & 4 & 4 & 4 & 4 & 16 \\
\hline CA205 & 4 & 4 & 4 & 4 & 16 \\
\hline CA116 & 4 & 4 & 3 & 4 & 15 \\
\hline LA202 & 4 & 4 & 3 & 4 & 15 \\
\hline LA112 & 4 & 4 & 4 & 2 & 14 \\
\hline CA105 & 4 & 4 & 4 & 1 & 13 \\
\hline CA111 & 4 & 4 & 4 & 1 & 13 \\
\hline CA104 & 4 & 4 & 3 & 2 & 13 \\
\hline CA213 & 4 & 4 & 4 & 0 & 12 \\
\hline CA214 & 4 & 4 & 4 & 0 & 12 \\
\hline R0102 & 4 & 4 & 4 & 0 & 12 \\
\hline R0101 & 4 & 4 & 4 & 0 & 12 \\
\hline LA102 & 4 & 4 & 4 & 0 & 12 \\
\hline LA110 & 4 & 4 & 4 & 0 & 12 \\
\hline LA201 & 4 & 4 & 4 & 0 & 12 \\
\hline LA210 & 4 & 4 & 4 & 0 & 12 \\
\hline CA202 & 4 & 4 & 3 & 0 & 11 \\
\hline CA217 & 3 & 4 & 4 & 0 & 11 \\
\hline CA113 & 4 & 3 & 3 & 0 & 10 \\
\hline CA207 & 4 & 3 & 2 & 0 & 9 \\
\hline CA209 & 4 & 2 & 3 & 0 & 9 \\
\hline CA208 & 4 & 3 & 1 & 0 & 8 \\
\hline R0106 & 4 & 4 & 0 & 0 & 8 \\
\hline RO105 & 4 & 3 & 0 & 0 & 7 \\
\hline
\end{tabular}

\begin{tabular}{l|l|l|l|l|l|l|} 
Score & 0 & 1 & 2 & 3 & 4 \\
\hline
\end{tabular}

Figure 5. Growth of $K$. marxianus strains at different temperatures $\left(27,42,45\right.$, and $\left.48{ }^{\circ} \mathrm{C}\right)$. Scores were obtained as the total number of spots for which growth at each dilution was evident. A heatmap-like color scale was adopted as a proxy for numerical values varying from red (no growth, or 0 points) to dark green (four spots/dilution). Strains were ordered based on decreasing total score.

\subsection{Whey Fermentation}

Twelve K. marxianus strains representative of different temperature scores and with different mating type (namely $7 \mathrm{MATa} / M A T \alpha, 4 M A T \mathrm{a}$, and 1 MATa) were randomly chosen to ferment whey. Two W. pararugosa (LA118 and LA218) and one T. delbrueckii (RO204-3) strains were also considered for comparative purposes. Growth in whey was monitored as weight loss over time and the resulting $\mathrm{CO}_{2}$ evolution trends were modeled in Grofit [50]. Fermentation trials in whey resulted in five curves fitted with Gompertz equation (CA111, LA102, LA210, LA118, and LA218), one curve with modified Gompertz equation (strain RO204-3), six curves with Richards model (strains CA104, CA105, CA116, CA204, CA213, and RO101) and the remaining three strains with logistics (strains CA207, CA214, LA202). Three characteristic parameters, namely $\lambda$ (lag phase), $\mu$ (growth rate), A (representing the maximum cell growth), were calculated from the model that best fit the data (Supplementary Table S1). As reported in Figure 6A K. marxianus CA213 and LA102 showed the highest growth rate in whey followed by strains CA207 CA111 and CA214, while W. pararugosa LA218 the lowest one $(p<0.05)$. T. delbrueckii RO204-3 started to release $\mathrm{CO}_{2}$ very late compared to other strains, resulting in low growth rate $(p<0.05)$. 


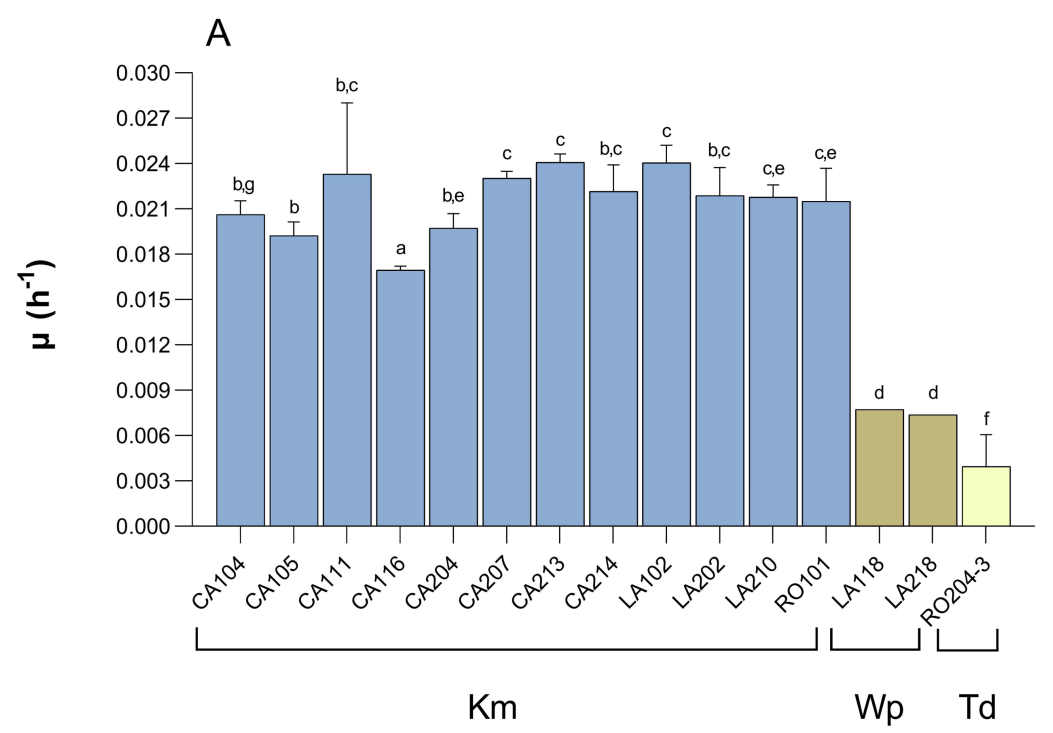

B

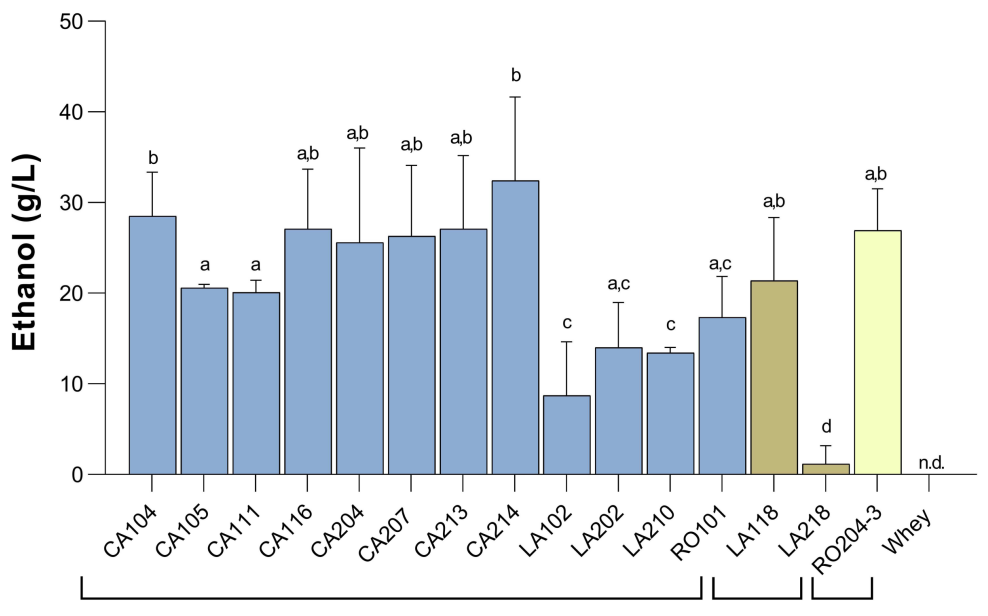

$\mathrm{Km}$

Wp Td

C

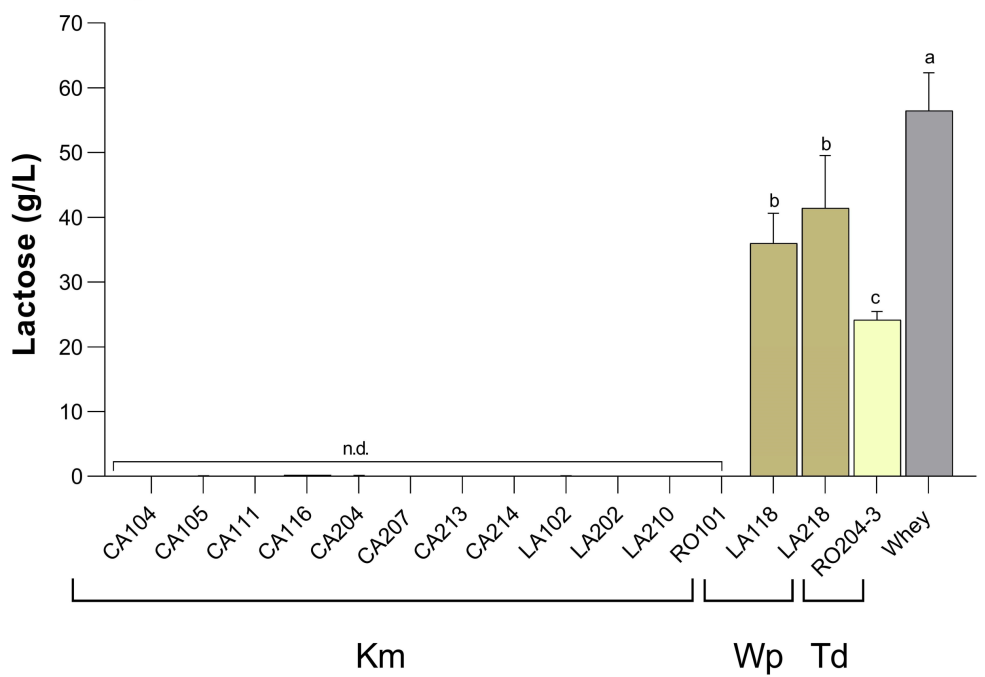

Figure 6. Growth rate (A), ethanol production (B), and lactose utilization (C) in whey fermentation trials. Details on strain isolation are in Table 2. Different letters mean significant differences $(p<0.05)$ among strains. Data are represented by the mean $(n=3)$; error bars show standard deviation. Abbreviations: Km, K. marxianus; Wp, W. pararugosa; $\mathrm{Td}$, T. delbrueckii; nd, not detected. 
The ethanol production and lactose consumption were determined at the end of whey fermentation trials. All the tested $K$. marxianus strains were able to convert lactose into ethanol, with strain CA214 being the most productive one $(32.45 \pm 9.18 \mathrm{~g} / \mathrm{L}$ of ethanol produced) followed by CA104, CA116, CA213, and CA207, which were able to release about $26-28 \mathrm{~g} / \mathrm{L}$ of ethanol in the medium. During whey fermentation by $K$. marxianus, the increase in ethanol production was accompanied by a disappearance in lactose concentration, which was undetectable or near to zero at the end of the fermentation. During alcoholic fermentation, the maximum ethanol production from hexoses (glucose and galactose) and lactose is 0.51 and $0.53 \mathrm{~g} / \mathrm{g}$, respectively. The total amount of lactose in whey was $56.7 \mathrm{~g} / \mathrm{L}$ whereas the total amount of hexoses (glucose and galactose) was $7.0 \mathrm{~g} / \mathrm{L}$. Taking into account these data, the maximum ethanol production should be $30.1 \mathrm{~g} / \mathrm{L}$ from lactose and 3.6 from hexoses (33.7 $\mathrm{g} / \mathrm{L}$ of ethanol maximum production). In the case of K. marxianus strain CA214, the final ethanol concentration was $32.45 \mathrm{~g} / \mathrm{L}$, suggesting an almost complete conversion of sugars in ethanol ( $96.3 \%$ of fermentation efficiency). In the case of K. marxianus CA104, CA116, CA213, and CA207 the calculated ethanol efficiency ranged from about 77 to $83 \%$. Previous studies reported ethanol efficiency of more than $70 \%$ for K. marxianus strains [53].

Lactose consumption was correlated with $\mathrm{CO}_{2}$ production and ethanol release for most of the K. marxianus strains, but not for W. pararugosa LA218 and T. delbrueckii RO204-3 (Figure 6B,C). In these strains, the slight consumption of lactose suggests the presence of $\beta$-galactosidase activity. Accordingly, Borelli et al. [54] and Andrade et al. [55] also reported T. delbrueckii dairy strains with $\beta$-galactosidase activity as specialized trait related to adaptation to isolation niche. However, in our strains, the ethanol production greatly exceeded the theoretical amount expected both from hexoses and lactose consumption. We can speculate a possible alternative pathway for ethanol production in these strains, such as the conversion of alanine or other amino acids into pyruvate, but further analyses are required to elucidate this point. In addition, for both these strains the low release of $\mathrm{CO}_{2}$ during the fermentation trials resulted very low growth rate (Figure 6A). We can speculate that the alleged lack of $\mathrm{CO}_{2}$ production might be an artifact from the gravimetric measurements, which can be masked by the strong increase in the biomass during fermentation.

\subsection{Proteolysis and Bioactive Peptide Characterization}

Dairy yeasts exhibit proteolytic behavior [56] and thus the potential for releasing bioactive peptides. This phenotype has been largely investigated in milk but poorly in whey. Recently, native microbiota of whey was proven to release bioactive peptides, but yeasts and $\mathrm{LAB}$ responsible for this proteolysis have been not characterized. In other works, K. marxianus and Debaryomyces hansenii generated antihypertensive peptides from the whey $\alpha$-lactalbumin and $\beta$-lactoglobulin, alone $[57,58]$ or in combination with LAB [59], but all these data arose from purified proteins and not from raw whey. Therefore, we determined whether whey proteins have been hydrolyzed by yeast fermentation. Figure 7 shows that the most proteolytic K. marxianus strains were CA105 and CA116 (amount of released free amino group of $17.0 \pm 1.0$ and $16.1 \pm 0.3 \mathrm{mmol} / \mathrm{L}$ of leucine equivalent, respectively). The only K. marxianus strain without any proteolytic activity was CA207. W. pararugosa and T. delbrueckii strains also showed proteolytic phenotype, with T. delbrueckii RO204-3 showing the highest activity (Figure 7).

The most proteolytic strains were selected for further high-resolution mass spectrometry analysis with the aim to identify the peptide profile. In particular, the samples analyzed were from whey fermented by T. delbrueckii RO204-3 and K. marxianus CA105, CA116, CA214, LA202, and RO101. The full list of identified peptides and the full MS data are reported in Supplementary Tables S2-S7. Strain RO101 was the highest peptide producer (141 peptides), followed by CA214 (119 peptides) and CA105 (109 peptides). T. delbrueckii RO204-3 released the lowest number of peptides (75) (Figure 8). Yeasts proteases were active towards whey proteins especially $\beta$-lactoglobulin and, to a lesser extent, $\alpha$ lactalbumin. However, K. marxianus strains mainly hydrolyzed $\beta$-casein (Figure 8 ). Cheese 
whey used for fermentation trials derived from PR cheese production after casein clogging and precipitation. It contained a prevalence of serum proteins but also a minor part of non-precipitated caseins or larger water-soluble casein peptides, released by the action of endogenous milk proteases, chymosin or starter LAB, which remained in the whey during cheese manufacturing $[60,61]$. Despite their presence in higher amounts in whey, serum proteins were less hydrolyzed than $\beta$-casein. Differently from caseins, which are characterized by a flexible and open structure, whey proteins displayed a rigid globular structure recalcitrant to the hydrolysis by proteases $[62,63]$.

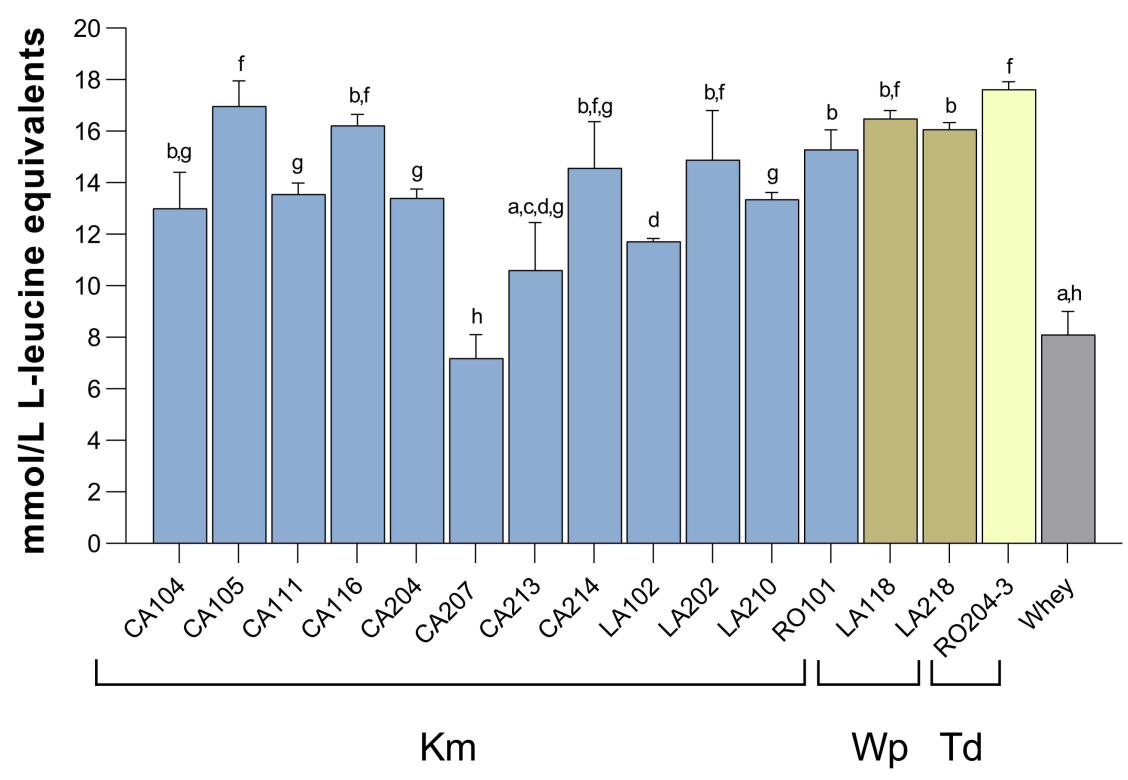

Figure 7. Proteolytic activity in fermented whey. The amount of released amino group was expressed as $\mathrm{mmol} / \mathrm{L}$ of leucine equivalents. Details on strain isolation are in Table 2. Different letters mean significant differences $(p<0.05)$ among strains. Data are represented as mean $(n=3)$; error bars show standard deviation. Abbreviations: Km, K. marxianus; Wp, W. pararugosa; Td, T. delbrueckii; nd, not detected.

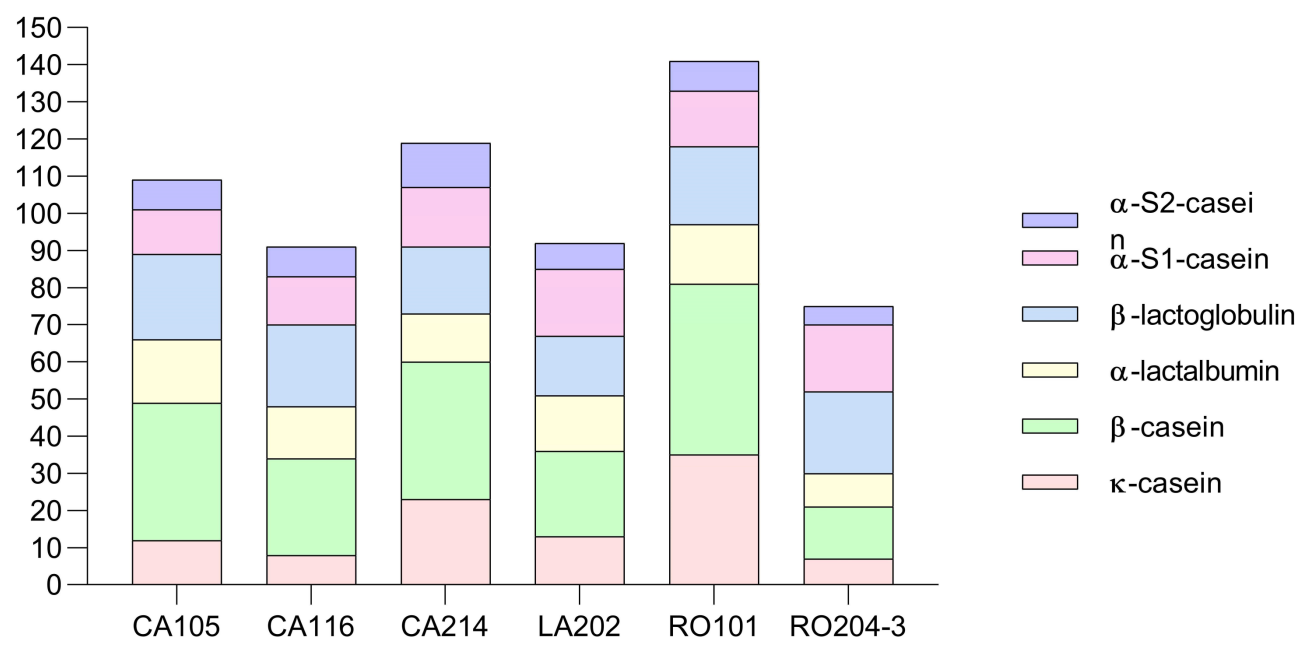

Figure 8. Number of identified peptides by mass spectrometry in fermented whey trials. Peptides are reported as function of the protein type. Details on strain isolation are in Table 2. 
Strains CA105 and RO101 were the most active towards whey proteins $\beta$-lactoglobulin and $\alpha$-lactalbumin (40 and 37 whey derived peptides, respectively). Comparison of peptide patterns revealed a low number of shared peptides (14), a signal of a great diversity of proteases responsible for hydrolytic process (Figure 9). As expected from different taxonomic position, T. delbrueckii RO204-3 showed 33 exclusive peptides (corresponding to the $44 \%$ of peptides identified), whereas five $K$. marxianus strains shared 35 peptides. The strains most similar in peptide profiles were CA214 and RO101 with 87 common peptides. Differently from the others, these strains were able to extensively hydrolyze the N-terminal region of $\beta$-casein and the $C$-terminal region of $k$-casein suggesting a similar specificity of the proteases involved in the hydrolytic process.

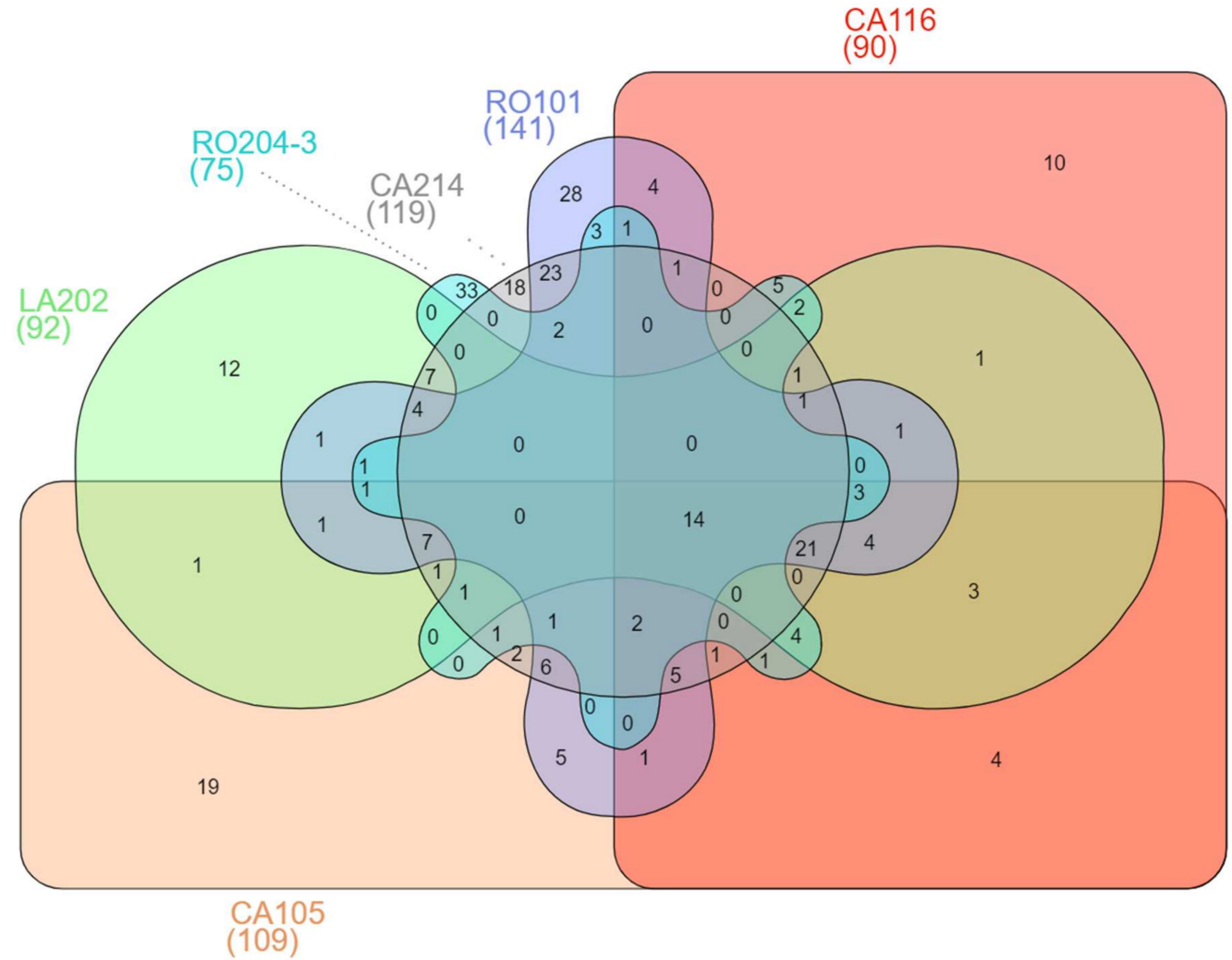

Figure 9. Venn diagram showing differences between the pattern of peptides released after whey fermentation by selected yeast strains. The complete list of peptides identified at the end of the fermentation trials by mass spectrometry can be found in Supplementary Tables S2-S7. Details on strain isolation are in Table 2.

Search in Milk Bioactive Peptides DataBase (MBPDB) allowed the identification of 22 bioactive peptides (100\% homology) (Table 3). Most of the bioactive peptides came from $\beta$-casein (13 bioactive peptides) and $\alpha$ S1-casein (four bioactive peptides) hydrolysis. Most of the identified bioactive peptides were angiotensin I-converting enzyme (ACE) inhibitors (13 peptides), anti-microbial (five peptides), and antioxidant (five peptides). The strain that produced the highest number of bioactive peptides was CA214 (14 bioactive peptides) followed by RO101 (10 bioactive peptides). Strain CA214 also released the highest number of ACE-inhibitory peptides (10 peptides) followed by RO101 (eight peptides) and CA105 (eight peptides). 
Table 3. Peptides scored in fermented whey with $100 \%$ sequence homology with previously demonstrated bioactive peptides. Abbreviation: ACE, angiotensin I-converting enzyme.

\begin{tabular}{|c|c|c|c|}
\hline $\begin{array}{l}\text { Protein } \\
\text { Precursor }\end{array}$ & Peptide Sequence & Biological Activity & Strains \\
\hline \multirow[t]{13}{*}{$\beta$-casein } & VYPFPGPIPN & $\begin{array}{c}\text { Antioxidant, } \\
\text { ACE-inhibitory }\end{array}$ & $\begin{array}{l}\text { CA105, CA116, LA202, } \\
\text { RO101 }\end{array}$ \\
\hline & SLPQ & ACE-inhibitory & CA214 \\
\hline & VVPP & ACE-inhibitory & CA214 \\
\hline & EAMAPK & Antimicrobial & CA214 \\
\hline & LHLPLP & ACE-inhibitory & $\begin{array}{c}\text { CA105, CA116, CA214, } \\
\text { LA202, RO101 }\end{array}$ \\
\hline & HQPHQPLPPT & ACE-inhibitory & CA105, CA116 \\
\hline & SQSKVLPVPQ & ACE-inhibitory & $\begin{array}{l}\text { CA105, CA116, CA214, } \\
\text { LA202, RO101, RO204-3 }\end{array}$ \\
\hline & SQSKVLPVPQKAVPYPQ & Antioxidant & RO204-3 \\
\hline & SKVLPVPQ & ACE-inhibitory & CA214 \\
\hline & KVLPVP & ACE-inhibitory & CA214, RO101 \\
\hline & KVLPVPQ & $\begin{array}{l}\text { ACE-inhibitory, } \\
\text { Anti-inflammatory }\end{array}$ & CA105, CA214, RO101 \\
\hline & KVLPVPQK & Antioxidant & RO101 \\
\hline & YQEPVLGPVR & $\begin{array}{c}\text { Antioxidant, } \\
\text { ACE-inhibitory, } \\
\text { Anti-inflammatory, } \\
\text { Antithrombotic, } \\
\text { Immunomodulatory }\end{array}$ & $\begin{array}{c}\text { CA105, CA214, LA202, } \\
\text { RO101 }\end{array}$ \\
\hline \multirow[t]{4}{*}{$\alpha$-S1-casein } & RPKHPIKHQ & ACE-inhibitory & $\begin{array}{c}\text { CA105, CA214, LA202, } \\
\text { RO204-3 }\end{array}$ \\
\hline & LRLKKYKVPQL & Antimicrobial & CA116, LA202, RO204-3 \\
\hline & PEL & Antioxidant & CA214, LA202 \\
\hline & SDIPNPIGSENSEK & Antimicrobial & RO204-3 \\
\hline K-casein & VESTVATL & Antimicrobial & CA214, RO101 \\
\hline \multirow[t]{2}{*}{$\begin{array}{c}\alpha- \\
\text { lactalbumin }\end{array}$} & YGL & ACE-inhibitory & CA105, RO101 \\
\hline & DKVGINYW & ACE-inhibitory & CA214, RO101 \\
\hline \multirow[t]{2}{*}{$\begin{array}{c}\beta- \\
\text { lactoglobulin }\end{array}$} & AVF & Anti-inflammatory & CA116, RO204-3 \\
\hline & VLVLDTDYK & $\begin{array}{l}\text { DPP-IV Inhibitory, } \\
\text { Antimicrobial }\end{array}$ & CA214, RO101 \\
\hline
\end{tabular}

\section{Conclusions}

Yeasts inhabiting NWS have been conventionally considered detrimental microorganisms which divert sugars from conversion to lactic acid by the action of starter LAB. Consequently, this microbial fraction has been considered neglectable so far. Here we demonstrated that PR NWS is a valuable reservoir of potential yeast cell factories to valorize whey through the fermentative production of ethanol and bioactive peptides. Yeast population in PR NWS is more complex than previously reported with more identified species other than the previously documented K. marxianus, such as T. delbrueckii, W. pararugosa, and S. cerevisiae. We also found that more than one biotype is present within each dominant species. Interestingly, while $S$. cerevisiae is unable to consume lactose and could be as secondary contaminant which uses sugars released by other microbes, T. delbrueckii and $W$. pararugosa strains exhibit a $\beta$-galactosidase activity to assimilate lactose. The genetic basis of this specialized trait required further investigations in the future to understand how these strains adapted to dairy environments. 
The pool of fast-fermenting K. marxianus strains identified in this study can valorize the sugar fraction of whey as they reached ethanol yield from $83.8 \%$ to app. 100\%. Remarkably, strain CA116 exhibits both thermotolerance until $48^{\circ} \mathrm{C}$ and high ethanol production, emerging as the best candidate for ethanol production from whey. Whey contains proteins other than sugar and can be utilized as raw material for producing beverages and hydrolysates enriched in bioactive peptides. This option has been mainly investigated through LAB fermentation, with a few attempts using yeasts. Here we demonstrated that K. marxianus and T. delbrueckii can release whey-derived bioactive peptides mainly with anti-hypertensive activity, opening a new avenue for the utilization of these strains as bioactive-peptide producers. Interestingly K. marxianus strain CA214 exhibits high ethanol yield and strongly ability to hydrolyze proteins releasing the highest amount of bioactive and ACE-inhibitory peptides. As reported above, identification of proteases responsible for this phenotype could assist future selection program and shed light on why these yeasts require proteolytic activity to survive in dairy environment.

Supplementary Materials: The following are available online at https://www.mdpi.com/article/ 10.3390/microorganisms9112288/s1, Figure S1. Multiple sequence alignment of 26S rRNA D1/D2 domain nucleotide sequences of $W$. pararugosa LA118 and LA206 with reference strain CBS1010 ${ }^{\mathrm{T}}$; Table S1. Kinetic growth parameters of selected $12 \mathrm{~K}$. marxianus strains, $2 \mathrm{~W}$. pararugosa and $1 \mathrm{~T}$. delbrueckii strain; Table S2. $\beta$-casein-derived peptides identified after whey fermentation by selected yeast strains; Table S3. $\alpha$ S1-casein-derived peptides identified after whey fermentation by selected yeast strains; Table S4. $\alpha$ S2-casein-derived peptides identified after whey fermentation by selected yeast strains; Table S5. $\mathrm{k}$-casein-derived peptides identified after whey fermentation by selected yeast strains; Table S6. $\alpha$-lactalbumin-derived peptides identified after whey fermentation by selected yeast strains; Table S7. $\beta$-lactoglobulin-derived peptides identified after whey fermentation by selected yeast strains $[39,40,50,64]$.

Author Contributions: Conceptualization, L.S.; methodology, L.S. and D.T.; software, S.M.; validation, S.M.; investigation, S.M., I.M. and M.B.; data curation, S.M., L.S. and D.T.; resources, V.P.; writing—original draft preparation, L.S.; writing—review and editing, S.M., I.M., M.B., V.P., D.T. and L.S.; funding acquisition, L.S. and D.T. All authors have read and agreed to the published version of the manuscript.

Funding: This work was funded by Fondo di Ateneo per la Ricerca FAR2020 granted by the Department of Life Sciences, University of Modena and Reggio Emilia, Italy.

Data Availability Statement: The nucleotide sequences of 26S rDNA D1/D2 domain are available in GenBank NCBI database under the accession numbers MZ491084 to MZ491094.

Conflicts of Interest: The authors declare no conflict of interest. The funders had no role in the design of the study; in the collection, analyses, or interpretation of data; in the writing of the manuscript, or in the decision to publish the results. V.P. is employed by Consorzio del Formaggio Parmigiano Reggiano. This does not alter the authors' adherence to all the journal policies on sharing data and materials.

\section{References}

1. Fróna, D.; Szenderák, J.; Harangi-Rákos, M. The Challenge of feeding the world. Sustainability 2019, 11, 5816. [CrossRef]

2. Ellen MacArthur Foundation. Available online: https:/ / www.ellenmacarthurfoundation.org/circular-economy/infographic (accessed on 24 June 2021).

3. Torres-León, C.; Ramírez-Guzman, N.; Londoño-Hernandez, L.; Martinez-Medina, G.A.; Díaz-Herrera, R.; Navarro-Macias, V.; Alvarez-Pérez, O.B.; Picazo, B.; Villarreal-Vázquez, M.; Ascacio-Valdes, J.; et al. Food Waste and Byproducts: An Opportunity to Minimize Malnutrition and Hunger in Developing Countries. Front. Sustain. Food Syst. 2018, 2, 52. [CrossRef]

4. Siso, M.I.G. The biotechnological utilization of cheese whey: A review. Bioresour. Technol. 1996, 57, 1-11. [CrossRef]

5. Zotta, T.; Solieri, L.; Iacumin, L.; Picozzi, C.; Gullo, M. Valorization of cheese whey using microbial fermentations. Appl. Microbiol. Biotechnol. 2020, 104, 2749-2764. [CrossRef] [PubMed]

6. Rao, M.; Bast, A.; de Boer, A. Valorized Food Processing By-Products in the EU: Finding the Balance between Safety, Nutrition, and Sustainability. Sustainability 2021, 13, 4428. [CrossRef] 
7. Gabardo, S.; Pereira, G.F.; Klein, M.P.; Rech, R.; Hertz, P.F.; Ayub, M.A.Z. Dynamics of Yeast Immobilized-cell Fluidized-bed Bioreactors Systems in Ethanol Fermentation from Lactose-hydrolyzed Whey and Whey Permeate. Bioprocess Biosyst. Eng. 2016, 39, 141-150. [CrossRef] [PubMed]

8. Venetsaneas, N.; Antonopoulou, G.; Stamatelatou, K.; Kornaros, M.; Lyberatos, G. Using cheese whey for hydrogen and methane generation in a two-stage continuous process with alternative $\mathrm{pH}$ controlling approaches. Bioresour. Technol. 2009, 100, $3713-3717$. [CrossRef]

9. Pandey, A.; Srivastava, S.; Rai, P.; Duke, M. Cheese whey to biohydrogen and useful organic acids: A non-pathogenic microbial treatment by L. acidophilus. Sci. Rep. 2019, 9, 1-9.

10. Kareb, O.; Aïder, M. Whey and Its Derivatives for Probiotics, Prebiotics, Synbiotics, and Functional Foods: A Critical Review. Probiotics Antimicrob. Prot. 2019, 11, 348-369. [CrossRef]

11. Lima, E.L.; Fernandes, J.; Cardarelli, H.R.; Lima, E.D.C.; Fernandes, J.D.; Cardarelli, H.R. Optimized fermentation of goat cheese whey with Lactococcus lactis for production of antilisterial bacteriocin-like substances. LWT Food Sci. Technol. 2017, 84, 710-716. [CrossRef]

12. Sabo, S.; Converti, A.; Ichiwaki, S.; Oliveira, R.P.S. Bacteriocin production by Lactobacillus plantarum ST16Pa in supplemented whey powder formulations. J. Dairy Sci. 2019, 102, 87-99. [CrossRef] [PubMed]

13. Chalermthai, B.; Chan, W.Y.; Bastidas-Oyanedel, J.R.; Taher, H.; Olsen, B.D.; Schmidt, J.E. Preparation and characterization of whey protein-based polymers produced from residual dairy streams. Polymers 2019, 11, 722. [CrossRef]

14. Li, C.; Ding, J.; Chen, D.; Shi, Z.; Wang, L. Bioconversion of cheese whey into a hetero-exopolysaccharide via a one-step bioprocess and its applications. Biochem. Eng. J. 2020, 161, 107701. [CrossRef]

15. Schultz, N.; Chang, L.; Hauck, A.; Reuss, M.; Syldatk, C. Microbial production of single-cell protein from deproteinized whey concentrates. Appl. Microbiol. Biotechnol. 2006, 69, 515-520. [CrossRef] [PubMed]

16. Sampaio, F.C.; Saraiva, T.L.C.; Silva, G.D.L.; Faria, J.T.; Pitangui, C.G.; Aliakbarian, B.; Perego, P.; Converti, A. Batch growth of Kluyveromyces lactis cells from deproteinized whey: Response surface methodology versus artificial neural network-Genetic algorithm approach. Biochem. Eng. J. 2016, 109, 305-311. [CrossRef]

17. Antunes, S.; Freitas, F.; Alves, V.D.C.; Grandfils, M.A. Reis Conversion of cheese whey into a fucose- and glucuronic acid-rich extracellular polysaccharide by Enterobacter A47. J. Biotechnol. 2015, 210, 1-7. [CrossRef]

18. Sinha, R.; Radha, C.; Prakash, J.; Kaul, P. Whey protein hydrolysate: Functional properties, nutritional quality and utilization in beverage formulation. Food Chem. 2007, 101, 1484-1491. [CrossRef]

19. Madureira, A.R.; Tavares, T.; Gomes, A.M.P.; Pintado, M.E.; Malcata, F.X. Invited Review: Physiological properties of bioactive peptides obtained from whey proteins. J. Dairy Sci. 2010, 93, 437-455. [CrossRef] [PubMed]

20. Yadav, J.S.S.; Song, Y.; Pilli, S.; Kumar, L.; Tyagi, R.D.; Surampalli, R.Y. Cheese whey: A potential resource to transform into bioprotein, functional/nutritional proteins and bioactive peptides. Biotechnol. Adv. 2015, 33, 756-774. [CrossRef]

21. Mazorra-Manzano, M.A.; Mora-Cortes, W.G.; Leandro-Roldan, M.M.; González-Velázquez, D.A.; Torres-Llanez, M.J.; RamírezSuarez, J.C.; González-Córdova, A.F.; Vallejo-Córdoba, B. Production of whey protein hydrolysates with angiotensin-converting enzyme- inhibitory activity using three new sources of plant proteases. Biocatal. Agric. Biotechnol. 2020, 28, 101724. [CrossRef]

22. Korhonen, H.; Pihlanto, A. Review: Bioactive peptides: Production and functionality. Int. Dairy J. 2016, 16, 945-960. [CrossRef]

23. Valdez Castillo, M.; Laxman Pachapur, V.; Brar, S.K.; Naghdi, M.; Arriaga, S.; Ávalos, R.A. Yeast-driven whey biorefining to produce value-added aroma, flavor, and antioxidant compounds: Technologies, challenges, and alternatives. Crit. Rev. Biotechnol. 2020, 40, 930-950. [CrossRef] [PubMed]

24. Solieri, L. The revenge of Zygosaccharomyces yeasts in food biotechnology and applied microbiology. World J. Microbiol. Biotechnol. 2021, 37, 96. [CrossRef]

25. Neviani, E.; Gatti, M.; Mucchetti, G.; Addeo, F. Considerazioni sul siero innesto naturale per Grana. Lattante 1998, 23 , 76-84.

26. Coppola, R.; Nanni, M.; Iorizzo, M.; Sorrentino, A.; Sorrentino, E.; Chiavari, C.; Grazia, L. Microbiological characteristics of Parmigiano Reggiano cheese during the cheesemaking and the first months of the ripening. Lait 2000, 80, 479-490. [CrossRef]

27. Neviani, E.; Carini, S. Microbiology of Parmesan cheese. Microbiol. Alim. Nutr. 1994, 12, 1-8.

28. Coppola, R.; Nanni, M.; Iorizzo, M.; Sorrentino, A.; Sorrentino, E.; Chiavari, C.; Grazia, L. Survey of lactic acid bacteria isolated during the avances stages of the ripening of Parmigiano Reggiano cheese. J. Dairy Res. 1997, 64, 305-310. [CrossRef]

29. Bottari, B.; Santarelli, M.; Neviani, E.; Gatti, M. Natural whey starter for Parmigiano Reggiano: Culture-independent approach. J. Appl. Microbiol. 2010, 108, 1676-1684. [CrossRef]

30. Zambonelli, C.; Montanari, G.; Passarelli, P.; Rainieri, S.I. Lieviti nei sieri acidi da formaggio Parmigiano Reggiano. Sci. Tec. Latt. Casearia 1996, 47, 261-270.

31. Coloretti, F.; Chiavari, C.; Luise, D.; Tofalo, R.; Fasoli, G.; Suzzi, G.; Grazia, L. Detection and identification of yeasts in natural whey starter for Parmigiano Reggiano cheese-making. Int. Dairy J. 2017, 66, 13-17. [CrossRef]

32. Leonel, L.V.; Arruda, P.V.; Chandel, A.K.; Felipe, M.G.A.; Sene, L. Kluyveromyces marxianus: A potential biocatalyst of renewable chemicals and lignocellulosic ethanol production. Crit. Rev. Biotechnol. 2021, 2, 1-22.

33. Aziz, H.-R.; Aslan, A.; Parvin, O.; Hadi, P. Kluyveromyces marxianus as a probiotic yeast: A mini-review. Curr. Nutr. Food Sci. 2020, $16,1163-1169$.

34. Karim, A.; Gerliani, N.; Aïder, M. Kluyveromyces marxianus: An emerging yeast cell factory for applications in food and biotechnology. Int. J. Food Microbiol. 2020, 333, 108818. [CrossRef] 
35. Anonymous. Säuregradbestimmung nach Soxhlet-Henkel (SH) [Titratable acidity evaluation with the Soxhlet-Henkel (SH) method]. Milchwissenschaft 1963, 18, 520.

36. Hoffman, C.S.; Winston, F. A ten-minute DNA preparation from yeast efficiently releases autonomous plasmids for transformaion of Escherichia coli. Gene 1987, 57, 267-272. [CrossRef]

37. White, T.J.; Bruns, T.; Lee, S.; Taylor, J. Amplification and direct sequencing of fungal ribosomal RNA genes for phylogenetics. In PCR Protocols: A Guide to Methods and Applications; Innis, M.A., Gelfand, D.H., Sninsky, J.J., White, T.J., Eds.; Academic Press: San Diego, CA, USA, 1990; pp. 315-322.

38. Kurtzman, C.P.; Robnett, C.J. Identification and phylogeny of ascomycetous yeasts from analysis of nuclear large subunit (26S) ribosomal DNA partial sequences. Antonie Leeuwenhoek 1998, 73, 331-371. [CrossRef] [PubMed]

39. Edgar, R.C. MUSCLE: Multiple sequence alignment with high accuracy and high throughput. Nucleic Acids. Res. 2004, 32, 1792-1797. [CrossRef]

40. Kumar, S.; Stecher, G.; Li, M.; Knyaz, C.; Tamura, K. MEGA X: Molecular Evolutionary Genetics Analysis across computing platforms. Mol. Biol. Evol. 2018, 35, 1547-1549. [CrossRef]

41. Letunic, I.; Bork, P. Interactive Tree of Life (iTOL) v4: Recent updates and new developments. Nucleic Acids Res. 2019, 2, 256-259. [CrossRef] [PubMed]

42. Dakal, T.C.; Solieri, L.; Giudici, P. Evaluation of fingerprinting techniques to assess genotype variation among Zygosaccharomyces strains. Food Microbiol. 2018, 72, 135-145. [CrossRef]

43. Lane, M.M.; Burke, N.; Karreman, R.; Wolfe, K.H.; O’Byrne, C.P.; Morrissey, J.P. Physiological and metabolic diversity in the yeast Kluyveromyces marxianus. Antonie Leeuwenhoek 2011, 100, 507-519. [CrossRef]

44. Fasoli, G.; Barrio, E.; Tofalo, R.; Suzzi, G.; Belloch, C. Multilocus analysis reveals large genetic diversity in Kluyveromyces marxianus strains isolated from Parmigiano Reggiano and Pecorino di Farindola cheeses. Int. J. Food Microbiol. 2016, 233, 1-10. [CrossRef]

45. Solieri, L.; Dakal, T.c.; Bicciato, S. Quantitative phenotypic analysis of multistress response in Zygosaccharomyces rouxii complex. FEMS Yeast Res. 2014, 14, 586-600. [CrossRef] [PubMed]

46. Tofalo, R.; Fasoli, G.; Schirone, M.; Perpetuini, G.; Pepe, A.; Corsetti, A.; Suzzi, G. The predominance, biodiversity and biotechnological properties of Kluyveromyces marxianus in the production of Pecorino di Farindola cheese. Int. J. Food Microbiol. 2014, 187, 41-49. [CrossRef] [PubMed]

47. Adler-Nissen, J. Determination of the degree of hydrolysis of food protein hydrolysates by trinitrobenzenesulfonic acid. J. Agric. Food Chem. 1979, 27, 1256-1262. [CrossRef]

48. Martini, S.; Solieri, L.; Cattivelli, A.; Pizzamiglio, V.; Tagliazucchi, D. An Integrated Peptidomics and In Silico Approach to Identify Novel Anti-Diabetic Peptides in Parmigiano-Reggiano Cheese. Biology 2021, 10, 563. [CrossRef] [PubMed]

49. Nielsen, S.D.; Beverly, R.L.; Qu, Y.; Dallas, D.C. Milk bioactive peptide database: A comprehensive database of milk proteinderived bioactive peptides and novel visualization. Food Chem. 2017, 232, 673-682. [CrossRef] [PubMed]

50. Kahm, M.; Hasenbrink, G.; Lichtenberg-Fraté, H.; Ludwig, J.; Kschischo, M. Grofit: Fitting Biological Growth Curves with R. J. Stat. Softw. 2010, 33, 1-21. [CrossRef]

51. Herskowitz, I. Life cycle of the budding yeast Saccharomyces cerevisiae. Microbiol. Rev. 1988, 52, 536-553. [CrossRef]

52. Fonseca, G.G.; Heinzle, E.; Wittmann, C.; Gombert, A.K. The yeast Kluyveromyces marxianus and its biotechnological potential. Appl. Microbiol. Biotechnol. 2008, 79, 339-354. [CrossRef] [PubMed]

53. Koushki, M.; Jafari, M.; Azizi, M. Comparison of ethanol production from cheese whey permeate by two yeast strains. J. Food. Sci. Technol. 2012, 49, 614-619. [CrossRef] [PubMed]

54. Borelli, B.M.; Ferreira, E.G.; Lacerda, I.C.A.; Franco, G.R.; Rosa, C.A. Yeast populations associated with the artisanal cheese produced in the region of Serra da Canastra, Brazil. World J. Microbiol. Biotechnol. 2006, 22, 1115-1119. [CrossRef]

55. Andrade, R.P.; Melo, C.N.; Genisheva, Z.; Schwan, R.F.; Duarte, W.F. Yeasts from Canastra cheese production process: Isolation and evaluation of their potential for cheese whey fermentation. Food Res. Int. 2017, 91, 72-79. [CrossRef]

56. Jakobsen, M.; Narvhus, J. Yeasts and their possible beneficial and negative effects on the quality of dairy products. Int. Dairy J. 1996, 6, 755-768. [CrossRef]

57. García-Tejedor, A.; Padilla, B.; Salom, J.B.; Belloch, C.; Manzanares, P. Dairy yeasts produce milk protein-derived antihypertensive hydrolysates. Food Res. Int. 2013, 53, 203-208. [CrossRef]

58. García-Tejedor, A.; Sánchez-Rivera, L.; Castelló-Ruiz, M.; Recio, I.; Salom, J.B.; Manzanares, P. Novel Antihypertensive LactoferrinDerived Peptides Produced by Kluyveromyces marxianus: Gastrointestinal Stability Profile and In Vivo Angiotensin I-Converting Enzyme (ACE) Inhibition. J. Agric. Food Chem. 2014, 62, 1609-1616. [CrossRef] [PubMed]

59. Hamme, V.; Sannier, F.; Piot, J.; Didelot, S.; Bordenave-Juchereau, S. Crude goat whey fermentation by Kluyveromyces marxianus and Lactobacillus rhamnosus: Contribution to proteolysis and ACE inhibitory activity. J. Dairy Res. 2009, 76, 152-157. [CrossRef]

60. Hallén, E.; Lundén, A.; Allmere, T.; Andrén, A. Casein retention in curd and loss of casein into whey at chimosin-induced coagulation of milk. J. Dairy Res. 2010, 77, 71-76. [CrossRef] [PubMed]

61. Ali, E.; Nielsen, S.D.; Abd-El Alal, S.; El-Leboudy, A.; Saleh, E.; LaPointe, G. Use of mass spectrometry to profile peptides in whey protein isolate medium fermented by Lactobacillus helveticus LH-2 and Lactobacillus acidophilus La-5. Front. Nutr. 2019, 6, 152. [CrossRef] [PubMed] 
62. Dupont, D.; Tomé, D. Milk proteins: Digestion and absorption in the gastrointestinal tract. In Milk Proteins. Milk Proteins from Expression to Food, 3rd ed.; Academic Press: Cambridge, MA, USA; Elsevier: Amsterdam, The Netherlands, 2020; pp. 701-714, ISBN 978-0128152515.

63. Dallas, D.C.; Guerrero, A.; Khaldi, N.; Castillo, P.A.; Martin, W.F.; Smilowitz, J.T.; Bevins, C.L.; Barile, D.; German, J.B.; Lebrilla C.B. Extensive in vivo human milk peptidomics reveals specific proteolysis yielding protective antimicrobial peptides. J. Proteome Res. 2013, 12, 2295-2304. [CrossRef]

64. Waterhouse, A.M.; Procter, J.B.; Martin, D.M.A.; Clamp, M.; Barton, G.J. Jalview Version 2-A multiple sequence alignment editor and analysis workbench. Bioinformatics 2009, 25, 1189-1191. 